Research Article

\title{
Study on Grey Correlation Degree Decision-Making Model for Investment Scheme on High-Grade Highways in Western China
}

\author{
Huihong Feng $\mathbb{D}^{1}{ }^{1}$ Tian Tang, ${ }^{1}$ Guohong Zhang, ${ }^{2}$ and Li Lu ${ }^{3}$ \\ ${ }^{1}$ School of Civil Engineering and Geomatics, Southwest Petroleum University, Chengdu 610500, China \\ ${ }^{2}$ Gansu Transportation Planning Survey and Design Institute Co., Ltd., Lanzhou 730030, China \\ ${ }^{3}$ Credit Department, Bank of China, Chengdu 610300, China \\ Correspondence should be addressed to Huihong Feng; fenghh163@163.com
}

Received 19 February 2020; Revised 30 May 2020; Accepted 9 June 2020; Published 17 July 2020

Academic Editor: Bonifacio Llamazares

Copyright (c) 2020 Huihong Feng et al. This is an open access article distributed under the Creative Commons Attribution License, which permits unrestricted use, distribution, and reproduction in any medium, provided the original work is properly cited.

Under the impact of the government's policies to expand domestic demand and maintain economic growth, the western area acquired a large amount of funding for infrastructure construction. The high-grade highways became the key project attracting investment because of its great development potential and strong transportation adaptability. However, the special geographical conditions in the western area created numerous barriers for the construction of high-grade highways, including many investment influencing factors, great investment risks and uncertainties, and high difficulty in defining the investment effect. In view of the goals in technical advancement and economic rationality for the investment scheme of high-grade highways, the possible influencing factors of the investment scheme decision-making of the high-grade highways in western China were first given comprehensive analysis. Through literature review and field investigation, 67 influencing factors of investment scheme decisionmaking were determined by the cost decomposition method and expert investigation method. Then, the influence degree of each factor was analyzed by using the Delphi method and entropy method. According to the sorting results, 49 important factors were reserved as the detailed index for investment scheme decision-making. Afterwards, the index system for investment scheme decision-making consisting of 2 target factors, 5 first-level indexes, 13 second-level indexes, and 49 third-level indexes was constructed. Based on this, the decision-making model of investment scheme for high-grade highways was established by combining Analytic Hierarchy Process (AHP) and grey theory. Specially, the standardized index matrix of investment scheme was determined by AHP, and the relation degree of each scheme was calculated by grey correlation degree, and then the optimal scheme was shaped by the size of comprehensive relation degree. Finally, the grey correlation degree decision-making model of the investment scheme was applied to a highway project located in Gansu province, China. The results showed that the optimal investment scheme determined by the decision model was consistent with the scheme actually adopted, indicating that the model has good operability and practicability. In this paper, a grey correlation degree decision-making model of investment scheme for high-grade highways in western China was proposed, providing an effective theoretical basis and valuable practical experience for the investment scheme decision-making of transportation infrastructure under special environments.

\section{Introduction}

Due to the fact that the gap between the eastern and western areas has been further widened with the rapid development of science and technology and economic level in China, the state implemented develop-the-west strategy and adopted a series of preferential policies, so as to accelerate the economic growth of the western areas and to solve the problem of unbalanced regional economic development in China. In this context, the western areas vigorously carry out the transportation infrastructure construction, including the high-grade highways and other projects, to improve the regional development environment, enhance regional accessibility, promote economic integration, and optimize the allocation of resources, thus to propel the rapid economic development in the western areas. During the period of "The $13^{\text {th }}$ Five-year Plan," the expected total investment for a highway project in western China reaches RMB 4.9 trillion 
or more. The provincial secondary highways and above accounts for more than $70 \%$, which means that each city and each county has the secondary highways. Meanwhile, the newly added mileage of high-grade highways is expected to reach $25000 \mathrm{~km}$ or more, almost doubling the length in "The $12^{\text {nd }}$ Five-year Plan." Compared with other projects, the difficulty of investment scheme decision-making for highgrade highways in western China is greatly reinforced due to existing characteristics including fixed financing channels, complicated investment structure, slow turnover of construction funds, and special regional environment. In order to avoid the phenomena that investment cannot reach expected effect because of decision-making errors and that it will result in unnecessary waste, it is urgent to conduct overall planning and integration of high-grade highways in western China, which is beneficial for the benign development of the highway construction in western China, and to conduct comprehensive studies on the investment scheme decision-making when facing the government's abundant investment.

The investment scheme decision-making refers to the process of selecting and optimizing investment scheme from both technical and economic aspects [1]. Its application and research have already been carried out worldwide. Jules Dupuit [2] first proposed the concept of social benefits of public projects and insisted that social benefits should be regarded as the standard in the investment scheme decisionmaking of public projects. In the early $20^{\text {th }}$ century, western countries formulated new economic policies for government investment projects and gradually took the economic benefits of investment scheme decision-making into account [3]. In the middle of the $20^{\text {th }}$ century, the United Nations Industrial Development Organization (UNIDO) [4] compiled the Industrial Project Evaluation Manual, which makes decisions on investment scheme of developing countries from both financial evaluation and national economic evaluation perspectives, and improves the investment decision-making theories and methods of developing countries. In the end of the $20^{\text {th }}$ century, the systematic, integrated, and cooperative trends of investment scheme decision-making management are increasingly apparent with the rapid development of information technology [5].

In the practical application, Narula et al. [6], and others assessed the project benefit by using linear parameter programming. Compared with the practical situation, the assessment results indicate that this method has good applicability and can effectively guarantee the accuracy of the investment scheme decision-making. wang et al. [7] analyzed the significant influencing factors involved in the financial evaluation process according to the investment status of highway construction in China, which reduces the possibility of decision-making mistakes due to numerous influencing factors. Chen and Zhang [8] and others analyzed various risk factors involved in the investment scheme decision-making of highway construction projects, assessed the corresponding changes in cash flow, and obtained the cash flow containing risk factors. According to the risk assessment on the net present value by this way, it guarantees the accuracy of investment scheme decision-making from the risk perspective. Sun[9] studied multiple influencing factors of investment scheme decision-making by using the technical assistance project loan of a bank and established a multiobjective decision-making evaluation index system, which provides a foundation for the investment scheme decision-making. According to the matter-element model, the extension set, and correlation function theory in extenics subject, Zhan et al. [10] and others studied the investment scheme decision-making of highways, established the evaluation index system, and provided the index classification method and weight determination method, which effectively guarantees the rationality of the investment scheme decision-making. Combining with engineering practice, Chen [11] compared the advantages and disadvantages between the traditional decision-making model and the cost-benefit decision-making model, introduced the decision-making method and procedure of the cost-benefit analysis method, and put forward suggestions on how to use this method in the investment scheme decision-making of highway traffic infrastructure. According to the relevant data of Guangxi highways, Wang [12] analyzed the main control factors influencing the investment scheme decision-making and established the regression model of Guangxi highway investment scheme, which provides a foundation for the investment scheme decision-making. Using information technology, Ma et al. [13] and others designed an auxiliary decision-making system for highway investment, providing an intuitive and visual auxiliary decision-making tool for the investment scheme decision-making.

Grey correlation degree is a model to quantitatively analyze the integration degree between subsystems and systems [14] during system operation by calculating the correlation degree of subsystems (different factors) among systems. At present, it has been applied in various fields and has achieved certain results. Yuan et al. used grey correlation analysis to evaluate the energy consumption, carbon dioxide emissions, and growth patterns in China's provincial transportation sector [15]. Wu et al. [16], Zhang, and others studied the grey multiattribute decision-making problems and applied the established grey decision-making model to supplier selection and enterprise investment analysis. Hsu and Chen $[17,18]$ proposed an improved model according to the grey correlation degree method and applied it to the long-term prediction of power demand in Taiwan. Fu [19] and others analyzed factors influencing slope stability by using the grey correlation degree method. Using the grey correlation degree method, Su and Yang [20] and others sought the main factors influencing the value of highways and determined the linkage relationship among the factors.

Overall, there have been many scholars over the years conducting research on the investment scheme decisionmaking content and scope from the perspectives of project risks, costs, and benefits of the highway project. However, the study on investment scheme decision-making for highways in western China is relatively few in terms of economic rationality and technical advancement, especially the lack of targeted study on investment decision-making index factor and on evaluation model. Compared with general highway engineering, the investment scheme of 
high-grade highway in western China is affected by a variety of decision factors with great fuzziness. Given this, it is necessary using the grey correlation degree method to quantize various fuzziness and subjective factors, which will make the decision to be more scientific, reasonable, and reliable. Therefore, it is imperative to construct the index system of the investment scheme decision-making suitable for the high-grade highways project in western China and to establish the corresponding decision-making model, so as to ensure the expected effect and target of the investment scheme.

\section{Construction of the Investment Scheme Decision-Making Index System for the High- Grade Highways' Project in Western China}

\subsection{Research Procedure. Four specific steps are as follows:}

(1) Determine the influencing factors of investment scheme decision-making. In this paper, the cost decomposition method and expert investigation method were used for preliminarily determining various factors that may affect the investment scheme decision-making of the high-grade highways in western China.

(2) Construct the index system of investment scheme decision-making. In this step, the degree analysis of influencing factors was conducted and the key decision factors were screened out by using the Delphi method and entropy method to carry out and to screen out.

(3) Establish the investment scheme decision-making model. According to the established index system, the investment scheme decision-making model of high-grade highways was constructed by combining the analytic hierarchy process (AHP) and the grey correlation degree theory.

(4) The verification of model effect: through an example of the investment scheme decision-making of the high-grade highway in western China, the application effect of the established investment scheme decision-making model was verified.

For the specific research framework procedure, see Figure 1.

2.2. Determine the Influencing Factors of Investment Scheme Decision-Making. In order to ensure the technical advancement and economic rationality of the investment scheme of the high-grade highways in western China, the relevant influencing factors can be considered from the following five aspects: construction condition, technical ability, economic benefit, social benefit, and environmental benefit. According to field investigation, with reference to the Economic Evaluation Methods of Highway Construction Project and relevant standards [21-29], the diagram about influencing factors was finally determined by using cost decomposition method and combining with expert opinions. This diagram consists of 2 targets factors, 5 firstlevel factors, 13 second-level factors, and 67 third-level factors, as shown in Figure 2.

In Figure 2, 13 second-level factors consist of 67 thirdlevel factors (details below):

(1) Adaptability to natural conditions $A_{1}$ : location $A_{11}$; geological factor $A_{12}$; landform $A_{13}$; water regime $\mathrm{A}_{14}$; climate $\mathrm{A}_{15}$; and topography $\mathrm{A}_{16}$

(2) Adaptability to social conditions $A_{2}$ : government funding $\mathrm{A}_{21}$; policy $\mathrm{A}_{22}$; talents $\mathrm{A}_{23}$; support $\mathrm{A}_{24}$; tax incentives $A_{25}$; and market conditions $A_{26}$

(3) Survey and design capability $B_{1}$ : building scale $B_{11}$; technical standard $\mathrm{B}_{12}$; route trend $\mathrm{B}_{13}$; major control points $\mathrm{B}_{14}$; and traffic forecast quantity $\mathrm{B}_{15}$

(4) Construction technology capability $\mathrm{B}_{2}$ : construction technology of roadbed, road surface, water proof, and drainage system $\mathrm{B}_{21}$; construction technology of highway appurtenance $\mathrm{B}_{22}$; construction technology of bridge and culvert $\mathrm{B}_{23}$; application ability of new construction technology $\mathrm{B}_{24}$; safety of technical solutions $\mathrm{B}_{25}$; construction technology and operation $\mathrm{B}_{26}$; and comprehensive management capability of site construction $\mathrm{B}_{27}$

(5) Total investment estimation $\mathrm{C}_{1}$ : estimation of fixed assets $\mathrm{C}_{11}$; estimation of liquidity $\mathrm{C}_{12}$; and estimation of other costs $\mathrm{C}_{13}$

(6) Financial evaluation conclusion $\mathrm{C}_{2}$ : financial internal rate of return $\mathrm{C}_{21}$; capital gain rate $\mathrm{C}_{22}$; gain rate of all investment parties $\mathrm{C}_{23}$; financial net present value $\mathrm{C}_{24}$; investment payoff period $\mathrm{C}_{25}$; return on investment $\mathrm{C}_{26}$; payment date of loan $\mathrm{C}_{27}$; debt service coverage ratio $\mathrm{C}_{28}$; and debt-to-asset ratio $\mathrm{C}_{29}$

(7) National economic evaluation conclusion $\mathrm{C}_{3}$ : economic internal rate of return $\mathrm{C}_{31}$; economic net present value $\mathrm{C}_{32}$; economic benefit cost ratio $\mathrm{C}_{33}$; and economic Net Present Value Rate $\mathrm{C}_{34}$

(8) Social effects $D_{1}$ : influence rate of local employment $\mathrm{D}_{11}$; influence rate of local customs $\mathrm{D}_{12}$; influence rate of industrial structure $\mathrm{D}_{13}$; and influence rate of traffic distribution $\mathrm{D}_{14}$

(9) Land using effect $\mathrm{D}_{2}$ : immigrant resettlement rate $\mathrm{D}_{21}$; land acquisition rate $\mathrm{D}_{22}$; pipeline mobility $\mathrm{D}_{23}$; and traffic diversion rate $\mathrm{D}_{24}$

(10) Development effect among regions $D_{3}$ : resource development utilization $\mathrm{D}_{31}$; percentage of improvement in living standards $\mathrm{D}_{32}$; urbanization rate $\mathrm{D}_{33}$; and land structure optimization rate $\mathrm{D}_{34}$

(11) Environmental pollution control effect $E_{1}$ : ratio of water pollution control $\mathrm{E}_{11}$; ratio of air pollution control $\mathrm{E}_{12}$; ratio of noise pollution control $\mathrm{E}_{13}$; ratio of solid waste control $\mathrm{E}_{14}$; and ratio of liquid waste control $\mathrm{E}_{15}$

(12) Recovery effect of ecological damage $\mathrm{E}_{2}$ : soil erosion rate $\mathrm{E}_{21}$; reclamation rate of temporary ground $\mathrm{E}_{22}$; 


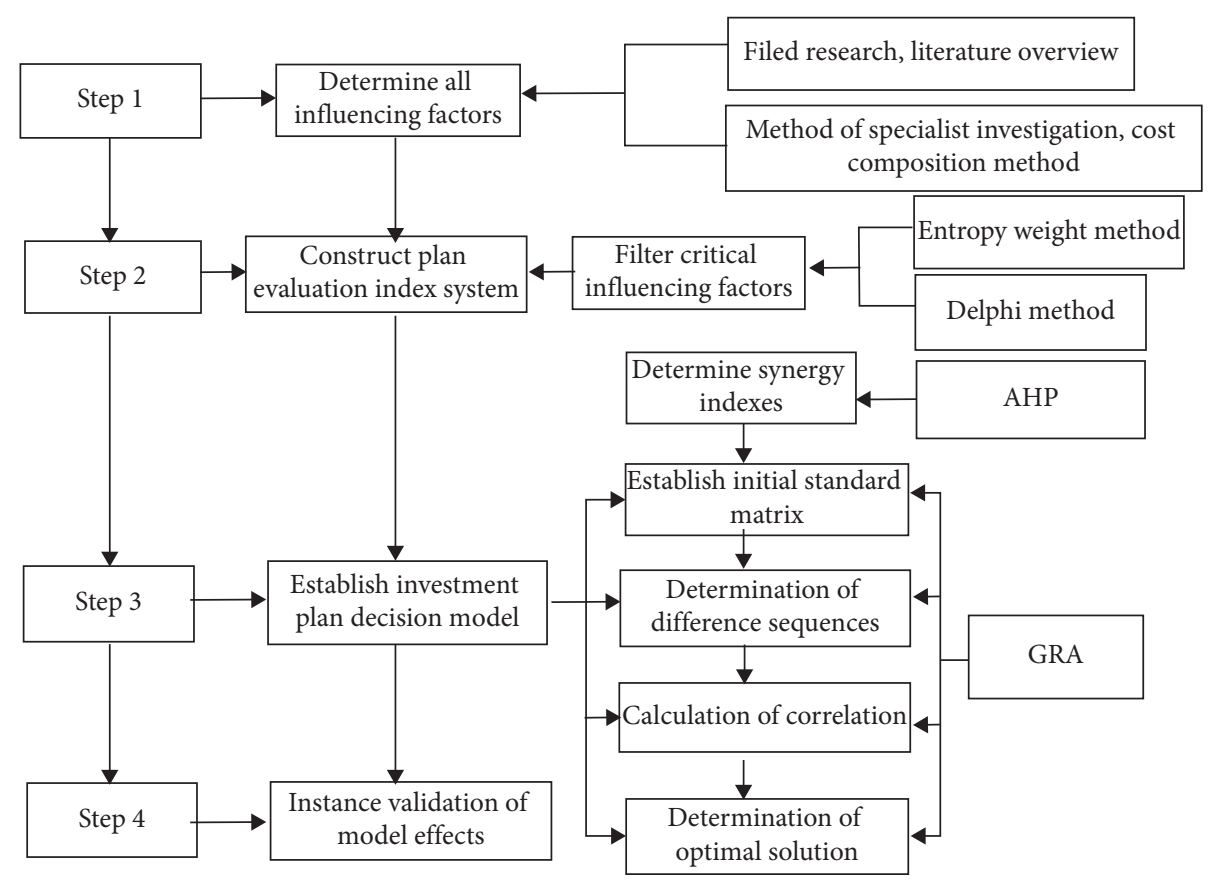

Figure 1: Schematic diagram of research framework.

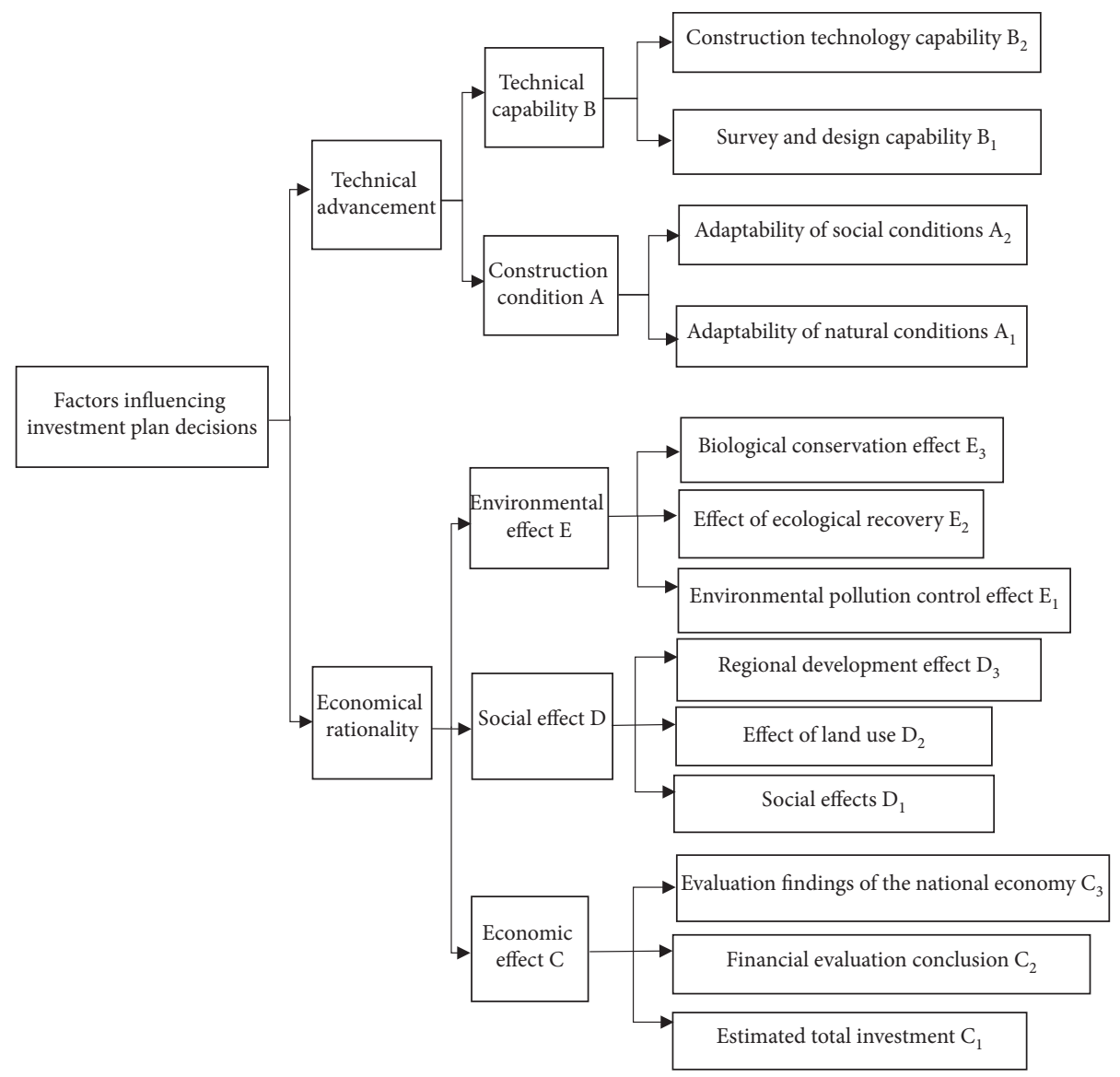

FIGURE 2: Factor graph of decision-making influence for investment plan for high-grade highway in the western region. 
implantation rate of green space $\mathrm{E}_{23}$; return rate of cultivated land $\mathrm{E}_{24}$; return rate of land fertility $\mathrm{E}_{25}$; and repair rate of Earth excavation $\mathrm{E}_{26}$

(13) Biological conservation effect $E_{3}$ : survival rate $E_{31}$; vegetation coverage $E_{32}$; species protection rate $E_{33}$; and crop growth rate $\mathrm{E}_{34}$

2.3. Screening Key Decision Factors by Entropy Method. In the diagram about influencing factors, some factors, the key factors of the decision-making, may have a significant impact on the investment scheme decision-making of highgrade highways, which could cause results unacceptable to the builder. Project builders should devote limited energy and resources to the analysis and research of key decision factors, so it is significant to screen out them from numerous influencing factors.

The entropy method is an objective evaluation method that can reduce subjective interference. Specially, the greater the changes of the information are, the more information will be presented; the greater the role in the comprehensive evaluation is, the more weight it is given to [30-32]. Considering the research conclusion of Bonifacio Llamazares, the entropy weight method has the disadvantage that the calculation result will be changed by the increase or decrease of alternatives in weight calculation [33]. However, this paper makes full use of the advantages and avoids the disadvantages and only uses the entropy weight method to calculate the weight of each index without evaluating the alternatives, and in the calculation process, only the degree of influence of the decision-making of high-grade highway project investment scheme in the western region is considered, rather than multiple alternatives, so the weight result will not be affected by the change of alternatives.

Based on this, due to the existence of a large number of influencing factors, it is necessary to fully consider different expert opinions. In order to avoid subjective influence, in this paper, the entropy method was used to screen out the key decision factors on the basis of considering the investment scheme target of high-grade highways and its characteristics and referring to opinions from technical and management experts.

2.3.1. Construct the Original Data Matrix. According to the scale of the influence degree of the investment scheme decision, each factor in the diagram about influencing factors was scored. The scoring criteria are shown in Table 1.

The selection of experts and the reliability test of the questionnaire before the evaluation of the impact factors are indispensable and necessary:

(1) Selection of experts: as high-level highway projects featuring high investment amounts, complex technical programs, and significant social and ecological impacts, their construction requires the cooperation of various departments involving experts in many fields including technology, management, and environment. In order to avoid scoring by experts in a single field or department and to ensure reasonable groups of experts, it
TABLE 1: Scoring criteria about influence degree on decisionmaking.

\begin{tabular}{lc}
\hline Influence degree on decision-making & Score \\
\hline High & 5 \\
Upper intermediate & 4 \\
Intermediate & 3 \\
Medium-low & 2 \\
Low & 1 \\
Between the adjacent influence degree & The average of adjacent \\
& numbers \\
\hline
\end{tabular}

is planned to select 30 experts to score from 6 related departments including government administration department, project out-contracting units, survey and design units, general construction contractors, project supervisors, and equipment purchasers. The structure of experts and their engaged fields is shown in Table 2 and Figure 3 below.

(2) Questionnaire reliability: the reliability of the questionnaire was analyzed using Cronbach's $\alpha$, which was calculated to be 0.884 by the SPSS software after discounting invalid questionnaires on the premise of the assurance of $100 \%$ recovery rate of questionnaire. It was shown in Table 3 that the questionnaire was acceptable, indicating that the results had high consistency and reliability, and could be used to calculate the index weight via the entropy method.

After expert selection and reliability analysis, first, according to Table 1, several experts were invited to score the influence degree of 67 decision influence factors by questionnaires, and the invalid questionnaires were removed. Then, according to the valid questionnaire score of each unit, the average score of each unit was calculated, until the entire mean values of 6 units were obtained. Finally, the original data matrix was constructed, as shown in matrix (1). To be specific, the number of rows $m$ represents the number of related departments and the number of columns nrepresents the number of third-level factor belonging to each secondary factor. Since there are 6 departments involved, the original data matrix is a matrix with six rows and $n$ columns:

$$
X=\left|\begin{array}{lll}
X_{11} & \ldots & X_{1 n} \\
X_{21} & \ldots & X_{2 n} \\
X_{m 1} & \ldots & X_{m n}
\end{array}\right| .
$$

For example, there are five third-level factors in survey and design capability $B_{1}$, the secondary factor, so the original data matrix $B_{1}$ is shown below:

$$
B_{1}=\left|\begin{array}{ccccc}
4 & 4.5 & 4 & 3.5 & 4 \\
3.5 & 4.5 & 4 & 4 & 4.5 \\
3.5 & 4 & 4 & 4 & 4.5 \\
4.5 & 4 & 3.5 & 3.5 & 4 \\
4 & 4.5 & 3.5 & 3.5 & 4 \\
3.5 & 4 & 4.5 & 4 & 4
\end{array}\right| .
$$


TABLE 2: Expert structure table.

\begin{tabular}{|c|c|c|c|c|c|}
\hline Main departments & $\begin{array}{l}\text { Number of } \\
\text { experts }\end{array}$ & Title structure & $\begin{array}{l}\text { Education } \\
\text { structure }\end{array}$ & $\begin{array}{l}\text { Seniority structure } \\
\text { of the major }\end{array}$ & $\begin{array}{l}\text { Age } \\
\text { structure }\end{array}$ \\
\hline Government of traffic management & 3 & $\begin{array}{l}\text { Senior engineer: } 1 \\
\text { Engineer: } 1 \\
\text { Economist: } 1\end{array}$ & $\begin{array}{c}\text { Doctor: } 1 \\
\text { Master: } 1 \\
\text { Undergraduate: } 1\end{array}$ & $\begin{array}{l}\geq 20 \text { years: } 2 \\
5 \sim 10 \text { years: } 1\end{array}$ & $\begin{array}{l}\geq 50 \text { years: } 1 \\
40 \sim 50 \text { year- } \\
\text { old: } 1 \\
30 \sim 40 \text { year- } \\
\text { old: } 1\end{array}$ \\
\hline $\begin{array}{l}\text { Department of highway engineering } \\
\text { construction }\end{array}$ & 6 & $\begin{array}{c}\text { Senior engineer: } 1 \\
\text { Engineer: } 2 \\
\text { Economist: } 1 \\
\text { Technician: } 1 \\
\text { Construction worker: } \\
1\end{array}$ & $\begin{array}{c}\text { Doctor: } 1 \\
\text { Master: } 2 \\
\text { Undergraduate: } 2 \\
\text { Specialist: } 1\end{array}$ & $\begin{array}{l}\geq 20 \text { years: } 2 \\
\text { 20 30 years: } 1 \\
\text { 10 20 years: } 1 \\
5 \sim 10 \text { years: } 1 \\
\leq 5 \text { years: } 1\end{array}$ & $\begin{array}{c}\geq 50 \text { year-old: } \\
1 \\
40 \sim 50 \text { year- } \\
\text { old: } 3 \\
30 \sim 40 \text { year- } \\
\text { old: } 1 \\
\leq 30 \text { year-old: } \\
1\end{array}$ \\
\hline $\begin{array}{l}\text { Department of highway engineering } \\
\text { supervision }\end{array}$ & 4 & $\begin{array}{c}\text { Chief management } \\
\text { engineer: } 1 \\
\text { Professional } \\
\text { Supervision } \\
\text { Engineer: } 1 \\
\text { Full-time supervisor: } \\
1 \\
\text { Technician: } 1\end{array}$ & $\begin{array}{c}\text { Doctor: } 1 \\
\text { Master: } 1 \\
\text { Undergraduate: } 2\end{array}$ & $\begin{array}{l}\geq 20 \text { years: } 1 \\
\text { 20 30 years: } 1 \\
\text { 10 20 years: } 1 \\
5 \sim 10 \text { years: } 1\end{array}$ & $\begin{array}{l}\geq 50 \text { year-old: } \\
1 \\
40 \sim 50 \text { year- } \\
\text { old: } 2 \\
30 \sim 40 \text { year- } \\
\text { old: } 1\end{array}$ \\
\hline $\begin{array}{l}\text { Department of highway engineering } \\
\text { survey and design }\end{array}$ & 6 & $\begin{array}{c}\text { Structural designer: } 1 \\
\text { Architect: } 2 \\
\text { Cost engineer: } 1 \\
\text { Designer: } 1 \\
\text { Construction site } \\
\text { personnel: } 1\end{array}$ & $\begin{array}{c}\text { Doctor: } 1 \\
\text { Master: } 2 \\
\text { Undergraduate: } 2 \\
\text { Specialist: } 1\end{array}$ & $\begin{array}{l}\geq 20 \text { years: } 2 \\
\text { 20 30 years: } 1 \\
\text { 10 20 years: } 1 \\
5 \sim 10 \text { years: } 1 \\
\leq 5 \text { years: } 1\end{array}$ & $\begin{array}{c}\geq 50 \text { year-old: } \\
1 \\
40 \sim 50 \text { year- } \\
\text { old: } 3 \\
30 \sim 40 \text { year- } \\
\text { old: } 1 \\
\leq 30 \text { year-old: } \\
1\end{array}$ \\
\hline $\begin{array}{l}\text { General contractor department of } \\
\text { highway engineering construction }\end{array}$ & 7 & $\begin{array}{c}\text { Senior engineer: } 2 \\
\text { Engineer: } 2 \\
\text { Cost engineer: } 1 \\
\text { Technician: } 1 \\
\text { Construction worker: } \\
1\end{array}$ & $\begin{array}{c}\text { Doctor: } 2 \\
\text { Master: } 2 \\
\text { Undergraduate: } 2 \\
\text { Specialist: } 1\end{array}$ & $\begin{array}{l}\geq 20 \text { years: } 2 \\
\text { 20 30 years: } 2 \\
\text { 10 20 years: } 1 \\
5 \sim 10 \text { years: } 1 \\
\leq 5 \text { years: } 1\end{array}$ & $\begin{array}{c}\geq 50 \text { year-old: } \\
2 \\
40 \sim 50 \text { year- } \\
\text { old: } 3 \\
30 \sim 40 \text { year- } \\
\text { old: } 1 \\
\leq 30 \text { year-old: } \\
1 \\
\end{array}$ \\
\hline $\begin{array}{l}\text { Department of highway engineering } \\
\text { equipment procurement }\end{array}$ & 4 & $\begin{array}{l}\text { Senior engineer: } 1 \\
\text { Engineer: } 1 \\
\text { Assistant engineer: } 1 \\
\text { Material staff: } 1\end{array}$ & $\begin{array}{c}\text { Doctor: } 1 \\
\text { Master: } 1 \\
\text { Undergraduate: } 2\end{array}$ & $\begin{array}{l}\geq 20 \text { years: } 1 \\
\text { 20 30 years: } 1 \\
\text { 10 20 years: } 1 \\
5 \sim 10 \text { years: } 1\end{array}$ & $\begin{array}{c}\geq 50 \text { year-old: } \\
1 \\
40 \sim 50 \text { year- } \\
\text { old: } 1 \\
30 \sim 40 \text { year- } \\
\text { old: } 1 \\
\leq 30 \text { year-old: } \\
1\end{array}$ \\
\hline
\end{tabular}

2.3.2. Determine Standard Matrix. After the original data matrix formula (1) was obtained, the forward index and the negative index were standardized, respectively, with standard formulas (3) and (4). Its purpose was to eliminate the dimensional gap among each index and to homogenize the heterogeneous index. Finally, the standard matrix formula (5) was obtained (details as follows):
Positive index: $r_{m n}=\frac{x_{m n}-\min \left\{x_{1 n}, \ldots, x_{m n}\right\}}{\max \left\{x_{1 n}, \ldots, x_{m n}\right\}-\min \left\{x_{1 n}, \ldots, x_{m n}\right\}}$

Negative index: $r_{m n}=\frac{\max \left\{x_{1 n}, \ldots, x_{m n}\right\}-x_{m n}}{\max \left\{x_{1 n}, \ldots, x_{m n}\right\}-\min \left\{x_{1 n}, \ldots, x_{m n}\right\}}$, 


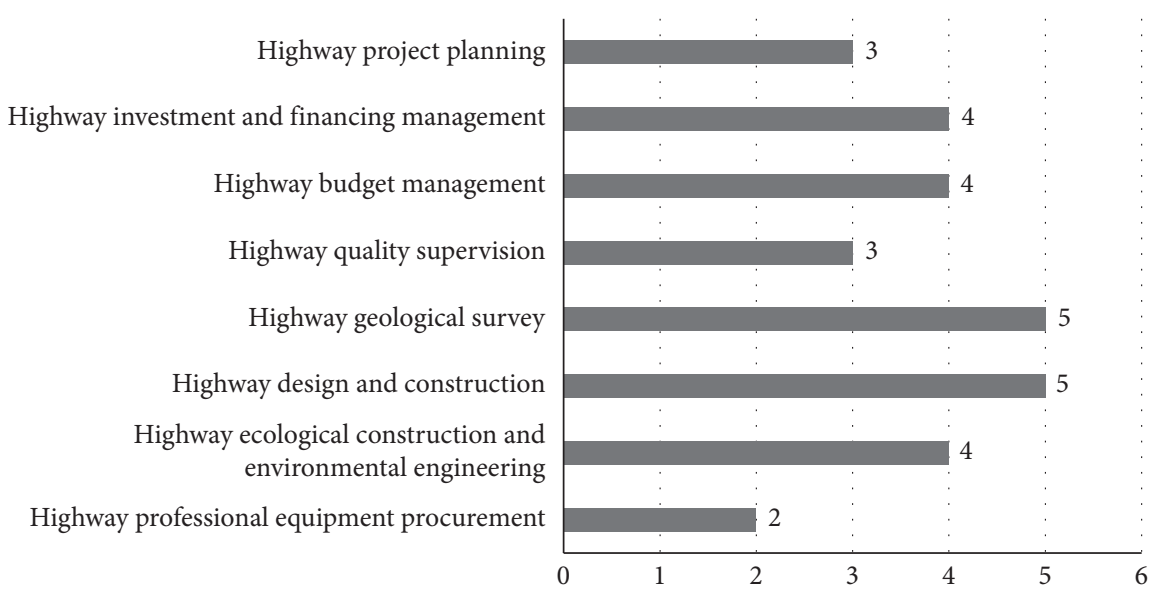

FIGURE 3: Expert domain structure.

TABLE 3: Value range of Cronbach's $\alpha$.

\begin{tabular}{|c|c|c|c|c|}
\hline $\begin{array}{l}\text { The } \\
\text { evaluation } \\
\text { results }\end{array}$ & Unacceptable & $\begin{array}{l}\text { Need to } \\
\text { revise }\end{array}$ & Acceptable & $\begin{array}{l}\text { High } \\
\text { reliability }\end{array}$ \\
\hline $\begin{array}{l}\text { Value } \\
\text { range }\end{array}$ & $\alpha<0.7$ & $0.7 \leq \alpha<0.8$ & $0.8 \leq \alpha<0.9$ & $\alpha \geq 0.9$ \\
\hline
\end{tabular}

For example, each third-level factor in $B_{1}$ is the positive index, which can be standardized according to standard formula (3). However, third-level factors such as the water pollution control rate and air pollution control rate in $E_{1}$ are the negative index, which can be standardized according to standard formula (4). The results are as follows:

$$
\begin{aligned}
& R_{B_{1}}=\left|\begin{array}{ccccc}
0.5 & 1 & 0.5 & 0 & 0.5 \\
0 & 1 & 0.5 & 0.5 & 1 \\
0 & 0.5 & 0.5 & 0.5 & 1 \\
1 & 0.5 & 0 & 0 & 0.5 \\
0.5 & 1 & 0 & 0 & 0.5 \\
0 & 0.5 & 1 & 0.5 & 0.5
\end{array}\right|, \\
& R_{E_{1}}=\left|\begin{array}{llll}
0 & \frac{1}{3} & \frac{2}{3} & \frac{1}{3} \\
\frac{1}{3} & \frac{2}{3} & 1 & \frac{2}{3} \\
\frac{1}{3} & \frac{1}{3} & \frac{2}{3} & \frac{1}{3} \\
\frac{1}{3} & \frac{2}{3} & \frac{1}{3} & \frac{1}{3} \\
\frac{1}{3} & \frac{2}{3} & \frac{2}{3} & \frac{2}{3} \\
0 & \frac{2}{3} & \frac{2}{3} & \frac{2}{3}
\end{array}\right|
\end{aligned}
$$

\subsubsection{Calculate Entropy Weight}

(1) Entropy Value Calculation. According to the characteristics of entropy, both the randomness of an event and dispersion degree of an index can be determined by calculating its entropy value. The larger the dispersion degree is, the more weight it is given to and the smaller the entropy value is.

The calculation formula of the entropy value of each decision influence factor is as follows:

$$
\begin{aligned}
f_{i j} & =\frac{r_{i j}}{\sum_{i=1}^{m} r_{i j}}, \quad j=1,2, \ldots, n, \\
K & =\frac{1}{\ln m}, \\
e_{j} & =-k \sum_{i=1}^{m} f_{i j} \times \ln f_{i j}, \quad j=1,2,3, \ldots, n,
\end{aligned}
$$

where $f_{i j}$ means uncertainty of information and the value of $K$ is always larger than zero.

(2) Calculation of Entropy Weight. The entropy weight can be calculated by using the given entropy value and following formula:

$$
w_{j}=\frac{\left(1-e_{j}\right)}{\sum_{j=1}^{n}\left(1-e_{j}\right)} .
$$

(3) Example for Computational Procedure. Taking $B_{1}$ as an example, the entropy value and entropy weight of its thirdlevel factors were calculated as follows and other factors like that as well:

(1) Uncertainty matrix $f_{B_{1}}$ was calculated by using standard formula (7): 


$$
f_{B_{1}}=\left|\begin{array}{ccccc}
0.25 & \frac{2}{9} & \frac{1}{5} & 0 & \frac{1}{8} \\
0 & \frac{2}{9} & \frac{1}{5} & \frac{1}{3} & \frac{1}{4} \\
0 & \frac{1}{9} & \frac{1}{5} & \frac{1}{3} & \frac{1}{4} \\
0.5 & \frac{1}{9} & 0 & 0 & \frac{1}{8} \\
0.25 & \frac{2}{9} & 0 & 0 & \frac{1}{8} \\
0 & \frac{1}{9} & \frac{2}{5} & \frac{1}{3} & \frac{1}{8}
\end{array}\right| .
$$

(2) After $K=(1 / \ln 6)$ was calculated by using formula (8), the entropy value of each third-level factor of $B_{1}$ was calculated by using formula (9). Then, the entropy weight of each third-level factor was calculated by using formula (10). The summarized results of entropy value and entropy weight are shown in Table 4.

2.4. Construct the Index System of Investment Scheme Decision-Making. According to results in Table 4, the qualified index was screened out with reference to the rule that the smaller the entropy value is, the larger the entropy weight is. The influence factors whose entropy value is small, such as $\mathrm{B}_{11}, \mathrm{~B}_{13}, \mathrm{~B}_{14}$, and $\mathrm{B}_{15}$, were chosen as key decision factors and the biggest entropy value $B_{12}$ was eliminated. The similar method was used to calculate the entropy value and entropy weight of other third-level factors. On the basis of ensuring richness of factors, 49 key decision factors were screened out from 67 third-level influencing factors according to the scale of entropy value. According to the scientific, comparable, systematic, and operable principles [34], the decisionmaking evaluation index system of investment scheme for high-grade highways in western China was determined, including 2 target levels, 5 first-level indexes, 13 second-level indexes, and 49 third-level indexes, as shown in Table 5.

\section{Establishment of Grey Correlation Degree Decision-Making Model of Investment Scheme for High-Grade Highways in Western China}

3.1. Applicability Analysis of Decision-Making Model Established by Grey Correlation Degree Method. Because of the predictive, comprehensive, and complex characteristics existed in investment decision-making process of high-grade highways in western China, as well as the uncertain and unquantifiable features for most indexes, it is essential to make scientific decision by utilizing the limited information and analyze its uncertainty.
TABLE 4: Summarized results of entropy value and entropy weight of each third-level factor.

\begin{tabular}{lcc}
\hline Third-level factor & Entropy value & Entropy weight \\
\hline Building scale $\mathrm{B}_{11}$ & 0.5803 & 0.076 \\
Technical standard $\mathrm{B}_{12}$ & 0.968 & 0.0058 \\
Route trend $\mathrm{B}_{13}$ & 0.384 & 0.112 \\
Major control point $\mathrm{B}_{14}$ & 0.613 & 0.071 \\
Traffic forecast quantity $\mathrm{B}_{15}$ & 0.967 & 0.00601 \\
\hline
\end{tabular}

At present, there are three common methods used for decision analysis and uncertainty system research, which are probability statistics method, fuzzy mathematics method, and grey correlation degree method. Comparison of the three methods is shown in Table 6.

It can be learned from Table 6 that Grey Correction Degree studies the uncertainty of poor information compared with the other two methods. It explores the motion law of objects with the effect of sequence operators and according to the existing information. It can build models based on only a little data and process grey objects with clear epitaxy and unclear connotation [35]. Besides, the investment plan decisions of high-grade highways in western region show grey characteristics and are a typical piece of poor information and a grey system. Therefore, it is applicable and feasible to apply Grey Correction Degree in making the investment plan decisions for high-grade highway projects in the western region $[36,37]$.

Based on this, the process to calculate with Grey Correction Degree and AHP for the purpose of building the decision-making model of the investment plan for highgrade highway in the western region is shown in Figure 4.

\subsection{Building of Decision-Making Model of Investment Plan}

3.2.1. Determination of Synergy Evaluation Indexes. As Analytic Hierarchy Process (AHP) can simplify decisionmaking problems with multiple objectives, multiple factors, and indexes that can be hardly quantified and needs less quantitative information, it matches with the grey characteristics of the decision-making process of the investment plan for high-grade highway in the western region. Therefore, Analytic Hierarchy Process (AHP) is used to calculate index weights when synergy evaluation indexes are determined. Firstly, recursion order hierarchy of indexes should be constructed; secondly, the pair judgment matrix should be constructed. Then, the index weight of all factors constituting the judgment matrix should be obtained through consistency inspection, and level-3 indexes that have the lowest weight within the group among level-2 indexes should be eliminated according to weight result. At last, the synergy evaluation indexes of the alternative plan can be obtained.

3.2.2. Determination of Initial Standard Index Matrix. Assume there are $m$ alternatives for the project, then select $n$ indexes from the index system to evaluate the synergy of alternatives and form the initial data matrix, and then 
TABLE 5: Decision-making evaluation index system of the investment scheme for high-grade highways in western China.

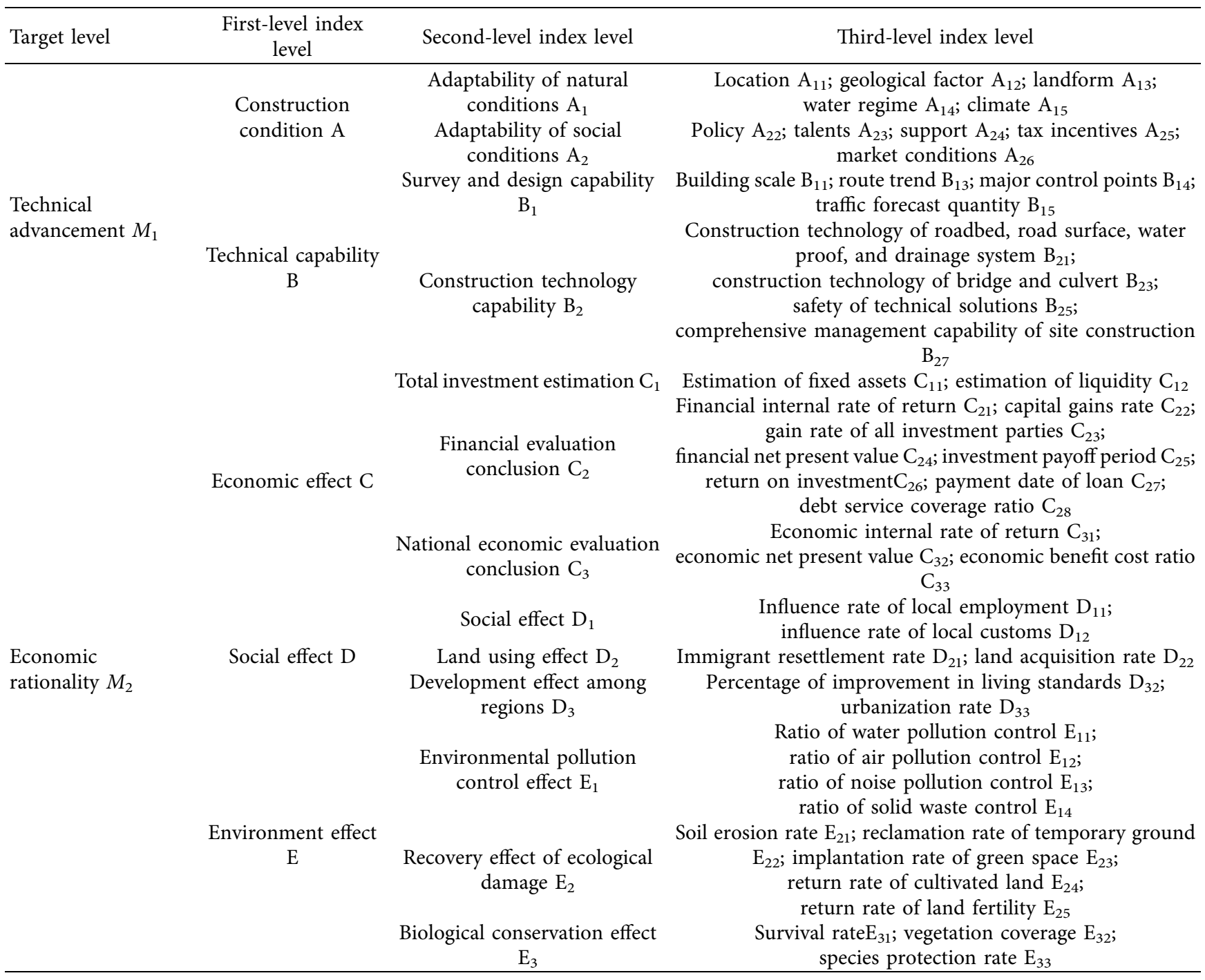

TABLE 6: Applicability comparison of decision-making methods.

\begin{tabular}{lccc}
\hline Applicability & Probability statistics & Fuzzy mathematics & Grey correlation degree \\
\hline Decision-making scheme & & & \\
Research object & Randomness & Uncertain perception & Poor information \\
Basic set & Cantor set & Fuzzy set & Grey obscure set \\
Method & Frequency statistics & Cut set & Grey sequence operator \\
Data demand & Canonical distribution & Available membership & Random distribution \\
Focus on results & Connotation & Denotation & Connotation \\
Research characteristics & Large sample & By experience & Small sample \\
\hline
\end{tabular}

implement dimensionless treatment with the method of the mean value to obtain the initial standard index matrix:

$$
X=\left(X_{i k}\right)_{m \times n}=\left[\begin{array}{cccc}
X_{11} & X_{21} & \cdots & X_{1 n} \\
X_{21} & X_{22} & \cdots & X_{2 n} \\
\cdots & \cdots & \cdots & \cdots \\
X_{m 1} & X_{m 2} & \cdots & X_{m n}
\end{array}\right] \text {, }
$$

where $i$ is the plan number, $i=1,2, \ldots, m$; $k$ is the number of evaluation index, $k=1,2, \ldots, n$; and $X_{i k}$ is the value of the index numbered $k$ of the plan numbered $i$.

3.2.3. Determination of Evaluation Standard Sequence. Select the maximum value $a_{o i}$ of each index in each plan to form reference sequence $X_{0}$ and then obtain 


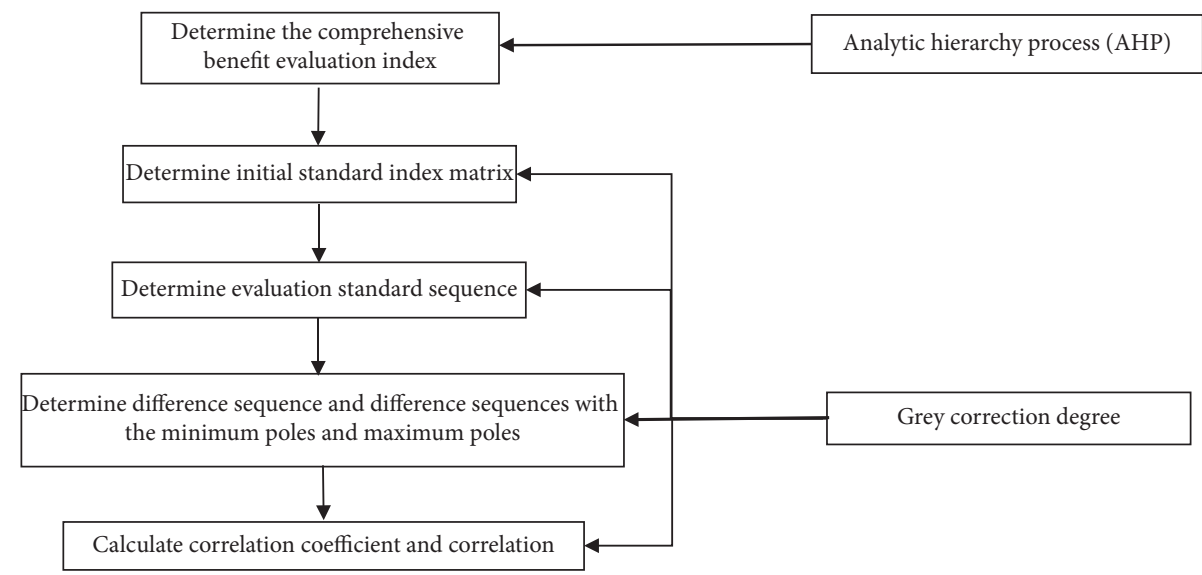

FIGURE 4: Process to calculate the decision-making model of the investment plan for high-class highway in the western region.

$$
X_{0}=\left(a_{01}, a_{02}, \ldots, a_{0 i}\right), \quad i=1,2, \ldots, n
$$

\subsubsection{Determination of Difference Sequence and Difference} Sequences with Minimum and Maximum Poles.

Difference sequence : $V_{0 i}=\left(V_{0 i}(1), V_{0 i}(2), \ldots, V_{0 i}(n)\right)$,

where

$V_{0 i}(k)=\left|X_{0}(k)-X_{i}(k)\right|, \quad i=1,2, \ldots, m ; k=1,2, \ldots, n$.
Difference sequences with minimum and maximum poles are

$$
\begin{gathered}
\max _{i} \max _{k}\left|X_{0}(k)-X_{i}(k)\right|=\max _{i} \max _{k}\left\{V_{0 i}(k)\right\}=V_{\text {max }}, \\
\min _{i} \min _{k}\left|X_{0}(k)-X_{i}(k)\right|=\min _{i} \min _{k}\left\{V_{0 i}(k)\right\}=V_{\text {min }},
\end{gathered}
$$

where $i=1,2, \ldots, m$ and $k=1,2, \ldots, n$.

3.2.5. Calculation of Correlation Coefficient

$$
\xi_{i}(k)=\frac{\min _{i} \min _{k}\left|X_{0}(k)-X_{i}(k)\right|+\xi \min _{i} \min _{k}\left|X_{0}(k)-X_{i}(k)\right|}{\left|X_{0}(k)-X_{i}(k)\right|+\xi \min _{i} \min _{k}\left|X_{0}(k)-X_{i}(k)\right|}=\frac{V_{\min }+\xi V_{\max }}{V_{0 i}(k)+\xi V_{\max }},
$$

where $i=1,2, \ldots, m$ and $k=1,2, \ldots, n ; \xi$ is recognition differential, $\xi \in(0.1,1)$, and generally taken as 0.5 ; and $\xi_{i}(k)$ means the correlation coefficient between the index numbered $k$ of the alternative plan numbered $i$ and the optimal value of the index numbered $k$.

3.2.6. Calculation of Correlation. In order to take the importance of indexes into full consideration and make the results more practical, the paper combines subjective and objective weights and determines weight through two-way combined weighting with the entropy weight method (objective weighting method) and AHP (subjective weighting method), making up for the deficiency in lateral focus on subjective or objective weight and making the weighting of all indexes more reasonable. Then, correlation calculation results are optimized accordingly. To be more specific, the weight optimization calculation formula is as

$$
W_{k}=\frac{W_{a_{k}} W_{b_{k}}}{\sum_{k}^{n} W_{a_{k}} W_{b_{k}}} .
$$

Then, the correlation value calculated with different weighting methods is the product of correlation coefficient and the weight used by each weighting method. The calculation formula is as

$$
r_{i}=\sum_{j=1}^{n} W_{j} \xi_{i}(k), \quad i=1,2, \ldots, n .
$$

At last, sequence sort plans in order according to value $r_{i}$ of the Grey Correction Degree. The larger the correlation, the closer the alternative plan to the reference sample and the better the overall level of the plan [38].

\section{Validation of Project Instances}

4.1. Project Profile. As shown in Figure 5, the highway, located in Lanzhou City, Gansu Province, is one of the 9 north-south longitudinal arterial highways that Lanzhou has planned. In the long run, it will connect many east-west arterial highways to from a large channel for regional traffic. The highway in this project is urban Level-I arterial highway, the designed running speed of which is $60 \mathrm{~km} / \mathrm{h}$. 


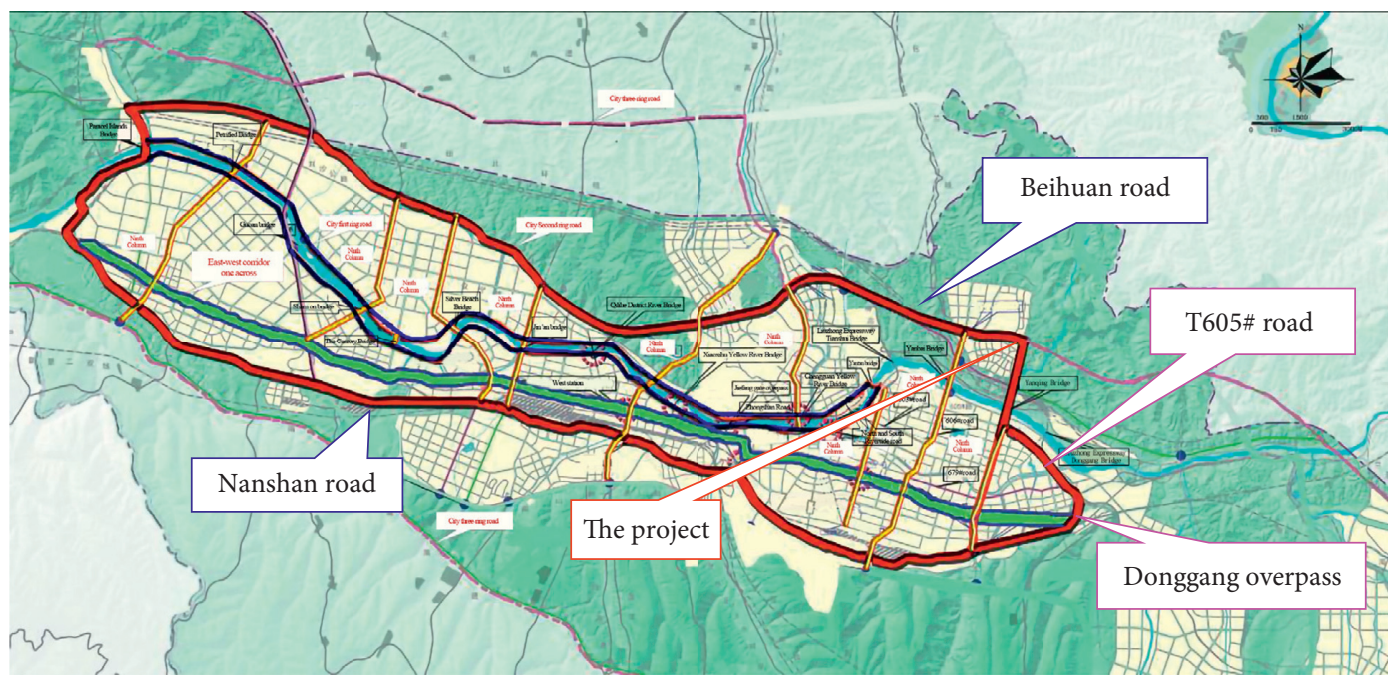

Figure 5: Planning map of related regions.

As a two-way 6-lane road, it has $33 \mathrm{~m}$ road breadth and $26 \mathrm{~m}$ bridge width.

In the project area, the geomorphic unit is Yellow River valley, and Yellow River inside the area flows from east to west. The existing topography is formed due to long-term erosion accumulation and alluvial of river. As a whole, the topographic relief is high. Within the project area, the special rock and soil are mainly collapsible loess, which is widely distributed in the project area. According to data of adjacent venues, the inner layer of silt inside the venue is not selfcollapsible and the collapsible foundation Earth has Grade II collapsibility. Besides, the thickness of collapsible loess is generally larger than $30 \mathrm{~m}$, and the self-collapsibility is Grade IZV. Unfavorable geology that may affect the highway to be built within the project area is mainly landslides, unsteady slopes, and debris flows. Local sliding has occurred on the slope surface, and landslides are not steady enough due to the erosion and scouring in the front edge within the toe channels resulting from seasonal drainage. Once a rainstorm or an earthquake happens, it is highly possible that this landslide becomes unsteady and slides again.

4.2. Alternative Investment Plans for the Project. Through specific feasibility analysis, direction of possible routes within the project area is studied in detail, and then 4 alternative plans, A, B, C, and D are determined. Comparison of the technical and economic indexes of all alternative plans is as shown in Table 7.

\subsection{Investment Plan Decision-Making Process Based on the Grey Correlation Degree Model}

4.3.1. Determination of Synergy Evaluation Indexes. According to the particularities of the project, the expert survey method was used, inviting 30 experts in all relevant fields (as shown in Table 2 and Figure 3 ) in the western region to score each indicator in the decision indicator system of the investment program. After passing the reliability test of the questionnaire, a pairwise judgment matrix for each index of each layer was established. Then, the judgment matrix was input into the MATLAB program to perform consistency check and get the weight of each index.

For example, the judgment matrix of 5 indexes, including construction condition A and technical capability B, is established on Class-1 index layer, as shown in Table 8.

It is obtained from consistency inspection: $\lambda_{\max }=5.1933$, C.I $=0.0483$, and C. $R=0.0431<0.1$, the compatibility of the judgment matrix is good and the weigh is $w=(0.1181,0.1916,0.3625,0.0634,0.2644)$.

Similarly, specialists score Class- 2 indexes and Class- 3 indexes in Class-2 indexes group; the pair judgment matrix is established and MATLAB software is used to analyze and calculate to obtain the weight of all indexes in the evaluation index system, as shown in Table 9 [39].

According to the calculation rate in Table 9, 15 Class- 3 indexes (climate condition $A_{15}$, tax preference $A_{25}$, critical control point $\mathrm{B}_{14}$, comprehensive management capability of field construction $B_{27}$, estimated fixed assets $C_{11}$, payback period $\mathrm{C}_{25}$, DSCR $\mathrm{C}_{28}$, economic effect-expense ratio $\mathrm{C}_{33}$, rate of influence on local customs $D_{12}$, resettlement rate $D_{21}$, rate of improvement of people's living standard $D_{32}$, noise treatment rate, $\mathrm{E}_{13}$, provisional land reclamation rate $\mathrm{E}_{22}$, and species protection rate $\mathrm{E}_{33}$ ) with the lowest weight within Class- 2 indexes group are eliminated, and the rest 34 Class- 3 indexes form the synergy evaluation index system of the project.

4.3.2. Determination of Initial Standard Indication Matrix. 30 experts were invited to score the system, of which the number of rows is the number of programs and the number of columns is the number of indicators. After passing the reliability test of the questionnaire, a grey correlation initial data matrix composed of 4 programs and 34 indicators was made. And the following initial standardized index matrix was made by the dimensionless method: 
TABLe 7: Comparison table of the technical and economic indexes of all alternative plans.

\begin{tabular}{|c|c|c|c|c|c|c|}
\hline No. & Item & Unit & Plan A & Plan B & Plan C & Plan D \\
\hline 1 & Highway class & - & Arterial highway & Arterial highway & Arterial highway & Arterial highway \\
\hline 2 & Design life & Year & 15 & 20 & 20 & 15 \\
\hline 3 & Route length & $\mathrm{km}$ & 1.275 & 1.1 & 1.132 & 1.018 \\
\hline 4 & Number of lanes & pcs & Two-way 4 lanes & Two-way 6 lanes & Two-way 6 lanes & Two-way 4 lanes \\
\hline 5 & Number of horizontal curves & pcs & 4 & 3 & 3 & 5 \\
\hline 6 & $\begin{array}{c}\text { Minimum radius of horizontal } \\
\text { curve }\end{array}$ & $\mathrm{m} / \mathrm{pcs}$ & $350 / 1$ & $400 / 1$ & $350 / 2$ & $380 / 2$ \\
\hline 7 & Maximum longitudinal grade & $\% / \mathrm{pcs}$ & $1.2 / 1$ & $1.0 / 1$ & $1.1 / 1$ & $1.1 / 1$ \\
\hline 8 & Earthwork $\quad$ Fill & $\mathrm{m}^{3}$ & $\begin{array}{l}87,662 \\
18,676\end{array}$ & $\begin{array}{l}74,763 \\
11,833\end{array}$ & $\begin{array}{l}89,100 \\
20,064\end{array}$ & $\begin{array}{l}90,140 \\
22,774\end{array}$ \\
\hline 9 & $\begin{array}{c}\text { Masonry of protection } \\
\text { engineering }\end{array}$ & $\mathrm{m}^{3}$ & 1,589 & 1,549 & 1,455 & 1,546 \\
\hline 10 & Treatment of special subgrade & $\mathrm{m}$ & 597 & 482.3 & 610 & 633.5 \\
\hline 11 & Subgrade width & $\mathrm{m}$ & 24.5 & 29 & 29 & 32 \\
\hline 12 & $\begin{array}{ll}\text { Asphalt concrete } \\
\text { Pavement }\end{array}$ & $\begin{array}{l}\mathrm{m}^{2} \\
\mathrm{~m}^{2}\end{array}$ & $\begin{array}{c}28,270 \\
-\end{array}$ & $\begin{array}{c}27,500 \\
-\end{array}$ & $\begin{array}{c}28,020 \\
-\end{array}$ & - \\
\hline 13 & Peak acceleration of Earth & g & 0.2 & 0.2 & 0.2 & 0.2 \\
\hline 14 & Bridge & $\mathrm{m} /$ building & 1 & 1 & 1 & 1 \\
\hline 15 & At-grade intersection & pcs & 3 & 2 & 6 & 5 \\
\hline 16 & Culvert and channel & pcs & 6 & 6 & 6 & 6 \\
\hline 17 & Demolished buildings & $\mathrm{m}^{2}$ & 36,270 & 28,400 & 44,451 & 49,127 \\
\hline 18 & Occupied land & $\mathrm{mu}$ & 94 & 86 & 89.4 & 91.3 \\
\hline 19 & Construction costs & RMB 10,000 & $6,544.8$ & $5,365.81$ & $6,975.1$ & $7,013.9$ \\
\hline
\end{tabular}

TABle 8: Pair judgment matrix of the criterion layer.

\begin{tabular}{lcccccc}
\hline A-B & A & B & C & D & E & Weight \\
\hline Construction condition A & 1 & $1 / 2$ & $1 / 3$ & 3 & 0.1181 \\
Technical capability B & 2 & 1 & $1 / 2$ & 4 & $1 / 3$ & 0.1916 \\
Economic effect C & 3 & 2 & 1 & 4 & 2 & 0.3625 \\
Social effect D & $1 / 3$ & $1 / 4$ & $1 / 4$ & 1 & $1 / 3$ & 0.0634 \\
Environmental effect E & 3 & 2 & $1 / 2$ & 3 & 1 & 0.2644 \\
\hline
\end{tabular}

$\begin{aligned} A= & =\left[\begin{array}{llllllllllllllllllll}0.769 & 0.938 & 0.882 & 0.769 & 1 & 0.833 & 1 & 1 & 0.667 & 0.769 & 0.625 & 0.833 & 0.833 & 0.938 & 1.111 & 0.833 & 0.625 \\ 1.154 & 0.625 & 0.588 & 1.154 & 1 & 1.111 & 1 & 1 & 1 & 1.154 & 1.25 & 1.111 & 1.111 & 0.625 & 0.833 & 1.111 & 0.938 \\ 1.154 & 0.938 & 1.176 & 1.154 & 1 & 1.111 & 1 & 1 & 1.333 & 1.154 & 1.25 & 1.111 & 1.111 & 0.938 & 0.833 & 1.111 & 0.938 \\ 0.769 & 1.25 & 1.176 & 0.769 & 1 & 0.833 & 1 & 1 & 0.667 & 0.769 & 0.625 & 0.833 & 0.833 & 1.25 & 1.111 & 0.833 & 1.25 \\ 1 & 1 & 0.769 & 0.833 & 0.769 & 0.833 & 1.176 & 0.588 & 0.789 & 0.714 & 0.625 & 0.789 & 0.681 & 0.833 & 0.833 & 0.870 & 0.870 \\ 1 & 1 & 1.154 & 1.111 & 1.154 & 1.111 & 1.176 & 1.176 & 1.053 & 1.071 & 0.938 & 1.053 & 1.136 & 1.111 & 1.111 & 1.087 & 1.087 \\ 1 & 1 & 1.154 & 1.111 & 1.154 & 1.111 & 0.882 & 1.176 & 1.053 & 1.071 & 0.938 & 1.053 & 1.136 & 1.111 & 1.111 & 1.087 & 1.087 \\ 1 & 1 & 0.769 & 0.833 & 0.769 & 0.833 & 0.588 & 0.882 & 1.053 & 1.071 & 1.25 & 1.053 & 0.909 & 0.833 & 0.833 & 0.870 & 0.870\end{array}\right] .\end{aligned}$

4.3.3. Determination of Evaluation Standard Sequence. According to the initial standard index matrix, evaluation standard sequence is formed by the maximum values of all indexes of each plan, and the result is as below:

$$
\begin{aligned}
A_{0}= & (1.154,1.25,1.176,1.154,1,1.111,1,1,1.333,1.154,1.25,1.111,1.111,1.25,1.111,1.111,1.25,1,1,1.154,1.111,1.154 \\
& 1.111,1.176,1.176,1.053,1.071,1.25,1.053,1.136,1.111,1.111,1.087,1.087)
\end{aligned}
$$


TABLE 9: Weight table of decision-making evaluation indexes of the investment plan of the project.

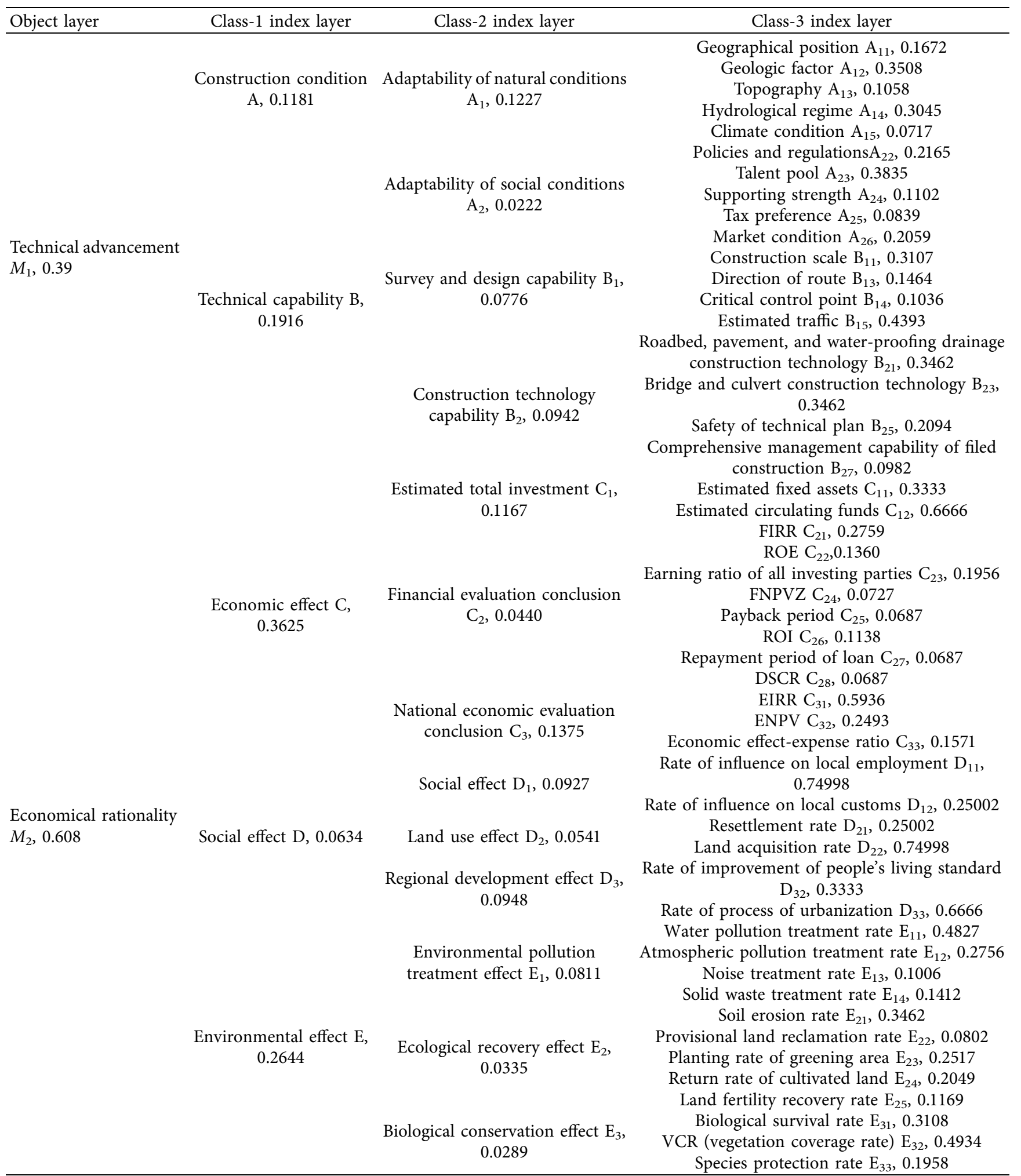


4.3.4. Determination of Difference Sequence and Difference Sequences with Minimum and Maximum Poles
(1) Determination of difference sequence:

$\begin{aligned} V_{o i} & =\left[\begin{array}{lllllllllllllllllll}0.385 & 0.313 & 0.294 & 0.385 & 0 & 0.278 & 0 & 0 & 0.667 & 0.385 & 0.625 & 0.278 & 0.278 & 0.313 & 0 & 0.278 & 0.625 \\ 0 & 0.625 & 0.588 & 0 & 0 & 0 & 0 & 0 & 0.333 & 0 & 0 & 0 & 0 & 0.625 & 0.278 & 0 & 0.313 \\ 0 & & 0.313 & 0 & 0 & 0 & 0 & 0 & 0 & 0 & 0 & 0 & 0 & 0 & 0.313 & 0.278 & 0 & 0.313 \\ 0.385 & 0 & & 0 & & 0.385 & 0 & 0.278 & 0 & 0 & 0.667 & 0.385 & 0.625 & 0.278 & 0.278 & 0 & 0 & 0.278 & 0 \\ & 0 & 0 & 0.385 & 0.278 & 0.385 & 0.278 & 0 & 0.588 & 0.263 & 0.357 & 0.625 & 0.263 & 0.455 & 0.278 & 0.278 & 0.217 & 0.217 \\ 0 & 0 & 0 & 0 & 0 & 0 & 0 & 0 & 0 & 0 & 0.313 & 0 & 0 & 0 & 0 & 0 & 0 & 0 \\ 0 & 0 & 0 & 0 & 0 & 0 & 0.294 & 0 & 0 & 0 & 0.313 & 0 & 0 & 0 & 0 & 0 & 0 \\ 0 & 0 & 0.385 & 0.278 & 0.385 & 0.278 & 0.588 & 0.294 & 0 & 0 & 0 & 0 & 0.227 & 0.278 & 0.278 & 0.217 & 0.217\end{array}\right],\end{aligned}$

(22) where $\quad V_{0 i}(k)=\left|X_{0}(k)-X_{i}(k)\right|, i=1,2, \ldots, m$ and $k=$ $1,2, \ldots, n$.
(2) Determination of maximum difference sequence and minimum difference sequence:

$$
\begin{aligned}
V_{\max }= & {[0.385,0.625,0.588,0.385,0,0.278,0,0,0.667,0.385,0.625,0.278,0.278,0.625,0.278,0.278,0.625,0,0,0.385,} \\
& 0.278,0.385,0.278,0.588,0.588,0.263,0.357,0.625,0.263,0.455,0.278,0.278,0.217,0.217], \\
V_{\min }= & {[0,0,0,0,0,0,0,0,0,0,0,0,0,0,0,0,0,0,0,0,0,0,0,0,0,0,0,0,0,0,0,0,0,0], }
\end{aligned}
$$

where the maximum value $\max \left(V_{\max }\right)=0.667 \mathrm{~min}$ $\left(V_{\min }\right)=0$.

$$
\begin{aligned}
\xi_{i}(k) & =\left[\begin{array}{llllllllllllllllllll}
0.464 & 0.516 & 0.531 & 0.464 & 1 & 0.545 & 1 & 1 & 0.333 & 0.464 & 0.348 & 0.545 & 0.545 & 0.516 & 1 & 0.545 & 0.348 \\
1 & & 0.348 & 0.362 & 1 & 1 & 1 & 1 & 1 & 0.5004 & 1 & 1 & 1 & 1 & 0.348 & 0.545 & 1 & 0.516 \\
1 & & 0.516 & 1 & & 1 & 1 & 1 & 1 & 1 & 1 & 1 & 1 & 1 & 1 & 0.516 & 0.545 & 1 & 0.516 \\
0.464 & 1 & & 1 & & 0.464 & 1 & 0.545 & 1 & 1 & 0.333 & 0.464 & 0.348 & 0.545 & 0.545 & 1 & 1 & 0.545 & 1 \\
1 & 1 & 0.464 & 0.545 & 0.464 & 0.545 & 1 & 0.362 & 0.559 & 0.483 & 0.348 & 0.559 & 0.423 & 0.545 & 0.545 & 0.606 & 0.606 \\
1 & 1 & 1 & 1 & 1 & 1 & 1 & 1 & 1 & 1 & 0.516 & 1 & 1 & 1 & 1 & 1 & 1 \\
1 & 1 & 1 & 1 & 1 & 1 & & 0.531 & 1 & 1 & 1 & 0.516 & 1 & 1 & 1 & 1 & 1 & 1 \\
1 & 1 & 0.464 & 0.545 & 0.464 & 0.545 & 0.362 & 0.531 & 1 & 1 & 1 & 1 & 0.595 & 0.545 & 0.545 & 0.606 & 0.606
\end{array}\right] .
\end{aligned}
$$

4.3.6. Calculation of Correlation. On the basis of considering the situation of the project itself, 30 experts were invited to score the 34 selected comprehensive benefit evaluation indicators. After passing the reliability test of the questionnaire, the out-of-group weights for each indicator were calculated by the analytic hierarchy process (AHP) and entropy method of MATLAB, and the optimal weights were calculated by formula (18), the results of which are shown in Table 10.

After the correlation coefficient is obtained, Grey Correlation Degree values corresponding to the weights for all
4.3.5. Calculation of Correlation Coefficient. Calculate $\xi_{i}(k)$ with formula (17). $\xi$ is taken as 0.5 to obtain the matrix of Grey Correlation Degree coefficients:

weighting methods can be obtained according to the results calculated with formula (19) and Table 10. All Grey Correlation Degree values obtained are summarized and sequenced. The sequencing result is as shown in Table 11.

\subsection{Decision Result Analysis}

4.4.1. Determination of Critical Decision Indexes according to Weight. Calculation results obtained with 3 weight methods in Table 10 are summarized, and weight distribution chart is 
TABLE 10: Summary table of the weights for all weighting methods.

\begin{tabular}{|c|c|c|c|c|c|c|}
\hline & $\mathrm{A}_{11}$ & $\mathrm{~A}_{12}$ & $\mathrm{~A}_{13}$ & $\mathrm{~A}_{14}$ & $\mathrm{~A}_{22}$ & $\mathrm{~A}_{23}$ \\
\hline AHP & 0.0274 & 0.0423 & 0.0214 & 0.0401 & 0.0147 & 0.032 \\
\hline Entropy weight method & 0.0481 & 0.0417 & 0.0165 & 0.0165 & 0.0118 & 0.0417 \\
\hline \multirow[t]{2}{*}{ Combination weight process } & 0.0484 & 0.0649 & 0.01299 & 0.0243 & 0.0064 & 0.049 \\
\hline & $\mathrm{A}_{24}$ & $\mathrm{~A}_{26}$ & $\mathrm{~B}_{11}$ & $\mathrm{~B}_{13}$ & $\mathrm{~B}_{15}$ & $\mathrm{~B}_{21}$ \\
\hline AHP & 0.0094 & 0.0141 & 0.0264 & 0.0205 & 0.0262 & 0.0560 \\
\hline Entropy weight method & 0.0084 & 0.0171 & 0.0165 & 0.0165 & 0.0084 & 0.0699 \\
\hline \multirow[t]{2}{*}{ Combination weight process } & 0.0029 & 0.0089 & 0.0160 & 0.0124 & 0.0081 & 0.144 \\
\hline & $\mathrm{B}_{23}$ & $\mathrm{~B}_{25}$ & $\mathrm{C}_{12}$ & $\mathrm{C}_{21}$ & $\mathrm{C}_{22}$ & $\mathrm{C}_{23}$ \\
\hline AHP & 0.0603 & 0.0365 & 0.0121 & 0.0152 & 0.0105 & 0.0113 \\
\hline Entropy weight method & 0.01598 & 0.0237 & 0.0282 & 0.029 & 0.0724 & 0.0453 \\
\hline \multirow[t]{2}{*}{ Combination weight process } & 0.0354 & 0.0318 & 0.0126 & 0.0162 & 0.0280 & 0.0188 \\
\hline & $\mathrm{C}_{24}$ & $\mathrm{C}_{26}$ & $\mathrm{C}_{31}$ & $\mathrm{C}_{32}$ & $\mathrm{D}_{11}$ & $\mathrm{D}_{22}$ \\
\hline AHP & 0.0094 & 0.0106 & 0.0128 & 0.0120 & 0.0133 & 0.0192 \\
\hline Entropy weight method & 0.0527 & 0.0593 & 0.0443 & 0.0455 & 0.0216 & 0.0247 \\
\hline \multirow[t]{2}{*}{ Combination weight process } & 0.0182 & 0.0231 & 0.0209 & 0.0201 & 0.0106 & 0.0174 \\
\hline & $\mathrm{D}_{33}$ & $E_{11}$ & $\mathrm{E}_{12}$ & $\mathrm{E}_{14}$ & $\mathrm{E}_{21}$ & $\mathrm{E}_{23}$ \\
\hline AHP & 0.0188 & 0.0534 & 0.0497 & 0.04 & 0.044 & 0.0405 \\
\hline Entropy weight method & 0.0472 & 0.0284 & 0.0247 & 0.0284 & 0.0162 & 0.0075 \\
\hline \multirow[t]{2}{*}{ Combination weight process } & 0.0326 & 0.0558 & 0.0452 & 0.0418 & 0.0262 & 0.0112 \\
\hline & $\mathrm{E}_{24}$ & $\mathrm{E}_{25}$ & $\mathrm{E}_{31}$ & & $\mathrm{E}_{32}$ & \\
\hline AHP & 0.0370 & 0.0361 & 0.0658 & & 0.0611 & \\
\hline Entropy weight method & 0.0237 & 0.0094 & 0.0232 & & 0.0154 & \\
\hline Combination weight process & 0.0323 & 0.0125 & 0.0562 & & 0.0346 & \\
\hline
\end{tabular}

TAвLE 11: Grey correlation values obtained with different weighting methods in the alternative plans for the project.

\begin{tabular}{lcccc}
\hline $\begin{array}{l}\text { Calculation } \\
\text { method }\end{array}$ & $\begin{array}{c}\text { AHP grey correlation } \\
\text { degree value }\end{array}$ & $\begin{array}{c}\text { Entropy weight method grey } \\
\text { correlation degree value }\end{array}$ & $\begin{array}{c}\text { Combination weight process grey } \\
\text { correlation degree value }\end{array}$ & $\begin{array}{c}\text { Grey correlation degree } \\
\text { sequencing result }\end{array}$ \\
\hline $\begin{array}{l}\text { Alternative plan } \\
\text { Plan A }\end{array}$ & 0.5515 & 0.5804 & & \\
Plan B & 0.8919 & 0.8769 & 0.5482 & 4 \\
Plan C & 0.9230 & 0.8951 & 0.8809 & 2 \\
Plan D & 0.6992 & 0.7115 & 0.9053 & 1 \\
\hline
\end{tabular}

drawn with 34 synergy indexes as the lateral axis and weight values as the vertical axis, as shown in Figure 6.

Weights calculated with the combination weight process, AHP, and entropy weight method are shown in Figure 6. Critical Class-2 decision indexes and corresponding critical Class-3 decision indexes of the project are obtained according to the figure, as shown in Table 12;

In sum up, in order to ensure plan investment effect, the critical decision indexes of the project should be

(1) Critical indexes that decide technical advancement: geologic factor $A_{12}$, talent pool $A_{23}$, technical capability of roadbed, pavement, and water-proofing drainage construction $\mathrm{B}_{21}$, and technical capability of bridge and culvert construction $\mathrm{B}_{23}$

(2) Critical indexes that decide economical rationality: ROE $C_{22}, F N P V C_{24}$, ROI $C_{26}$, water pollution treatment rate $E_{11}$, and biological survival rate $E_{31}$

4.4.2. Determination of Investment Plan according to Grey Correlation Degree. Based on correlation values and sequencing of all plans obtained in Table 11, the Grey Correlation Degree relationship chart of the alternative plans corresponding to three weighting methods, with the weighting method as lateral axis and Grey Correlation Degree value as the vertical axis, is shown in Figure 7.

According to the sequencing and distribution of correlations in Figure 7 and Table 11, main plan, alternative plan and optimization plan of the project can be obtained, and determined as below:

(1) Determination of main plan: from Table 11, it can be learned that the correlations calculated with the combination weight process, AHP, and entropy weight method can be sequenced. Plan $\mathrm{A}<$ Plan $\mathrm{D}<$ Plan $\mathrm{B}<$ Plan $\mathrm{C}$, which shows Plan $\mathrm{C}$ can bring the highest ROI. Therefore, Plan $\mathrm{C}$ should be selected as the main plan of the project.

(2) Determination of alternative plans: as the project is located in western geological environment, alternative plans should be determined as well, considering risks and uncertainties. Based on this, Plan B can be selected as the alternative plan to cope with the unforeseeable risks that might be met in the project construction process, as the correlation of Plan B is very close to that of Plan C (as shown in Figure 7). For example, geologic factor $\mathrm{A}_{12}$ cannot meet requirements if special subgrade is in construction 


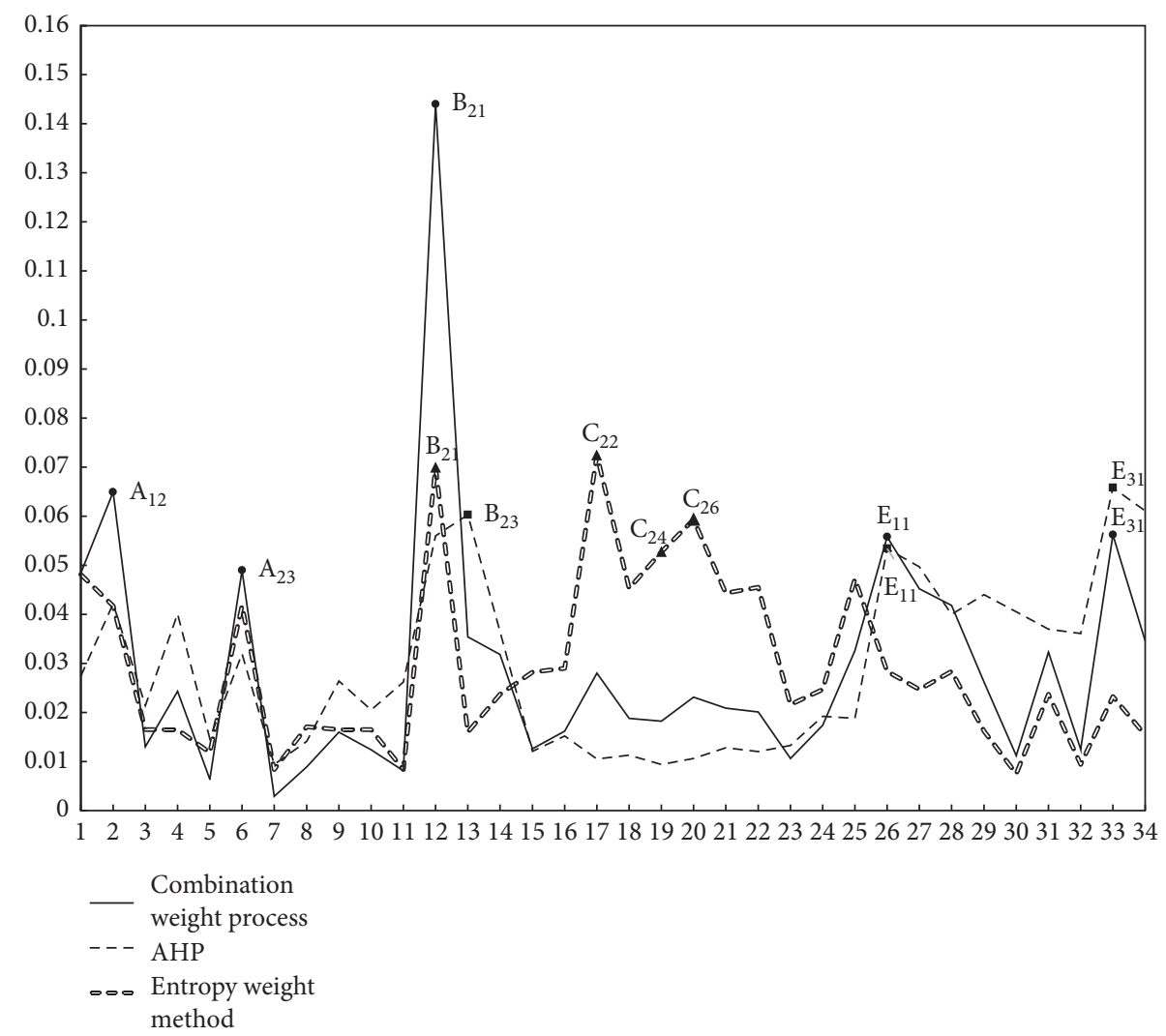

Figure 6: Weight distribution chart.

TABle 12: Table of critical decision indexes determined with 3 weighting methods.

\begin{tabular}{|c|c|c|c|}
\hline \multirow{2}{*}{ Weighting method } & \multirow{2}{*}{$\begin{array}{c}\text { Measurement } \\
\text { object }\end{array}$} & \multicolumn{2}{|r|}{ Critical decision index } \\
\hline & & Class-2 indexes & Class-3 indexes \\
\hline \multirow{5}{*}{$\begin{array}{l}\text { Combination weight } \\
\text { process }\end{array}$} & \multirow{3}{*}{$\begin{array}{c}\text { Technical } \\
\text { advancement }\end{array}$} & $\begin{array}{l}\text { Adaptability of natural } \\
\text { conditions } A_{1}\end{array}$ & Geologic factor $A_{12}$ \\
\hline & & $\begin{array}{c}\text { Adaptability of social } \\
\text { conditions } \mathrm{A}_{2}\end{array}$ & Talent pool $\mathrm{A}_{23}$ \\
\hline & & $\begin{array}{l}\text { Construction technology } \\
\text { capability } \mathrm{B}_{2}\end{array}$ & $\begin{array}{l}\text { Technical capability of roadbed, pavement, and water- } \\
\text { proofing drainage construction } B_{21}\end{array}$ \\
\hline & \multirow{2}{*}{$\begin{array}{l}\text { Economical } \\
\text { rationality }\end{array}$} & $\begin{array}{c}\text { Environmental treatment } \\
\text { effect } \mathrm{E}_{1}\end{array}$ & Water pollution treatment rate $\mathrm{E}_{11}$ \\
\hline & & $\begin{array}{l}\text { Ecological protection effect } \\
\qquad E_{3}\end{array}$ & Biological survival rate $E_{31}$ \\
\hline \multirow{3}{*}{ AHP } & $\begin{array}{c}\text { Technical } \\
\text { advancement }\end{array}$ & $\begin{array}{l}\text { Construction technology } \\
\text { capability } \mathrm{B}_{2}\end{array}$ & Technical capability of bridge and culvert construction $B_{23}$ \\
\hline & \multirow{2}{*}{$\begin{array}{l}\text { Economical } \\
\text { rationality }\end{array}$} & $\begin{array}{l}\text { Environmental treatment } \\
\text { effect } \mathrm{E}_{1}\end{array}$ & Water pollution treatment rate $E_{11}$ \\
\hline & & $\begin{array}{l}\text { Ecological protection effect } \\
\qquad E_{3}\end{array}$ & Biological survival rate $\mathrm{E}_{31}$ \\
\hline \multirow[b]{2}{*}{$\begin{array}{l}\text { Entropy weight } \\
\text { method }\end{array}$} & $\begin{array}{c}\text { Technical } \\
\text { advancement }\end{array}$ & $\begin{array}{l}\text { Construction technology } \\
\text { capability } \mathrm{B}_{2}\end{array}$ & $\begin{array}{l}\text { Technical capability of roadbed, pavement, and water- } \\
\text { proofing drainage construction } B_{21}\end{array}$ \\
\hline & $\begin{array}{l}\text { Economical } \\
\text { rationality }\end{array}$ & $\begin{array}{l}\text { Financial evaluation } \\
\text { conclusion } \mathrm{C}_{2}\end{array}$ & $\begin{array}{c}\text { ROE C }_{22} \\
\text { FNPV C }_{24} \\
\text { ROI C }_{26} \\
\end{array}$ \\
\hline
\end{tabular}

process, and the construction process of the subsequent bid sections of the whole highway can be thus affected. In such a case, Plan $\mathrm{B}$ and $\mathrm{C}$ can be combined, which means recombination on the established route, and can avoid soft soil ground as suggested in Plan $\mathrm{C}$ to make the new route meet 


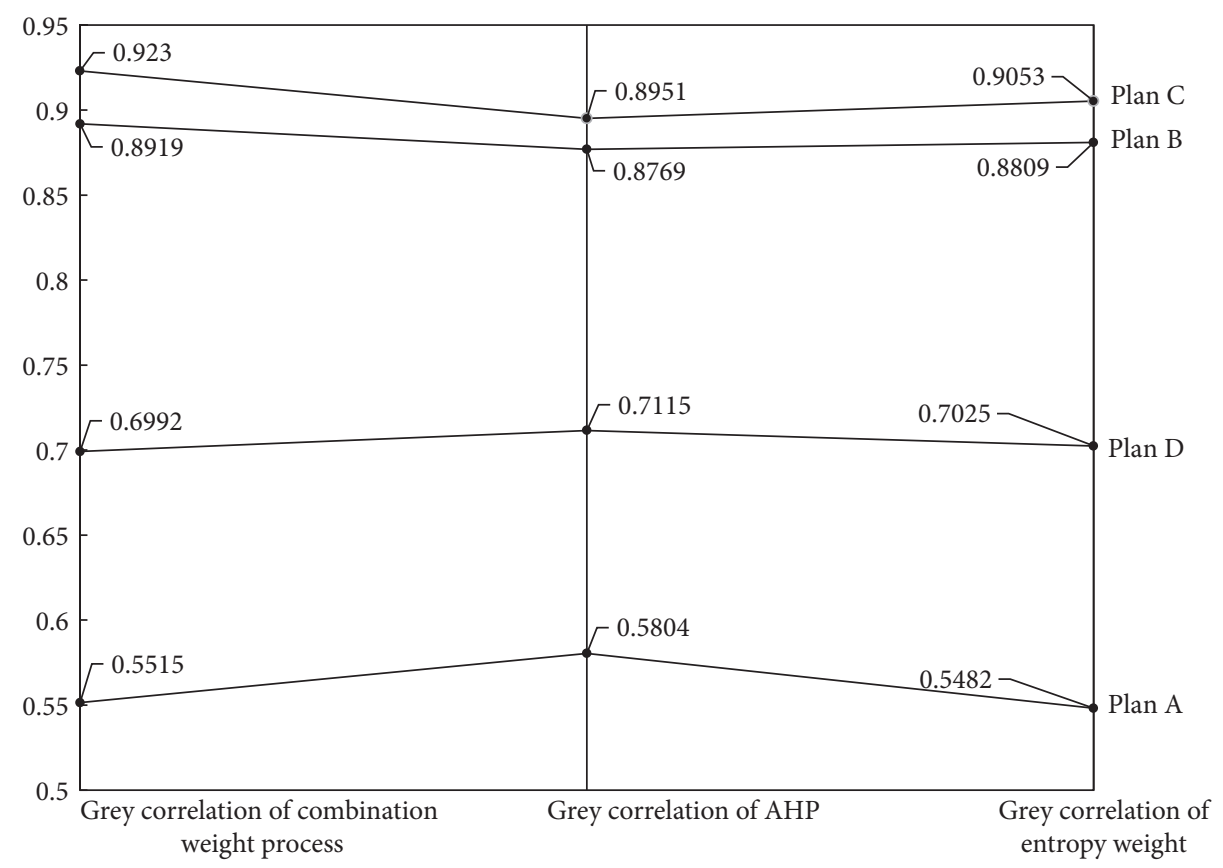

FIgURE 7: Grey correlation degree chart of alternative plans.

construction requirements, so as to ensure the smooth implementation of the plan.

(3) Optimization plan: although the correlation coefficient of Plan A and Plan D is small and there is a big gap between them and the correlation of Plan C (as shown in Figure 7), ideas that can be optimized and utilized in these two plans should still be considered comprehensively when Plan $\mathrm{C}$, the main plan, is implemented. For example, the established 6-lane design in Plan $\mathrm{C}$ is very inapplicable to certain road sections and is not necessary for some other sections due to estimated traffic reduction. In such a case, 4lane design and construction idea in Plan A and Plan $\mathrm{D}$ should be considered.

In summary, Plan C is taken as the main plan and Plan B is considered to be used as the alternative plan, and relevant content in Plan A and Plan D will be used as optimization ideas for Plan C.

\section{Conclusion}

With constant implementation of China Western Development, high speed economic development, and constant improvement of traffic infrastructures, it is of great significance to explore scientific, reasonable, and effective investment decision-making methods for high-grade highway projects. In this paper, factors that influence the investment plans for high-grade highway investment plans in western region are determined with the method of specialist investigation and cost composition method, and critical decision factors are filtered with the Delphi method and entropy weight method, in order to solve decision-making problems about high-grade highway investment plans in the western region. Besides, the decision-making index system for high-grade highway investment plans in the western region is established according to the above. Based on the decision-making index system, AHP and Grey Correction Degree are combined to establish the correlation model of investment plan decision. Through instance analysis, the result of this model decision matches with the actually adopted optimal plan the best, showing this model has better adaptability and operability.

Leveraging the objective weighting characteristics of the entropy weight method and taking the opinions of different specialists into consideration, objective influences are reduced and the decision-making factors of investment plans are filtered in this study to establish a decision-making index system for high-grade highway investment plans applicable to the western region. Taking advantages of Grey Correction Degree, i.e., less information and simplified decision-making problem, the Grey Correction Degree is used together with AHP to gather objective and subjective weights again, decision results are optimized with grey correlation, and a new decision-making correlation model of investment plans that meet the characteristics of high-grade highways in the western region is brought up, providing theoretical basis for the decision-making of high-grade highway investment plans under the same environmental background.

\section{Data Availability}

The data used to support the findings of this study are included within the article.

\section{Conflicts of Interest}

The authors declare no conflicts of interest. 


\section{Acknowledgments}

This research was funded by the Scientific Research Project of the State Administration of Work Safety (Sichuan-00052017AQ), Key Project of the Education Department of Sichuan Province (14ZA0048), and School-level Education Reform Project of Southwest Petroleum University (18YJYB25).

\section{References}

[1] M. S. Hu, P. Zhang, X. Wang et al., "Research on engineering cost control in investment decision-making stage of expressway project," Road Traffic Science and Technology (Applied Technology Edition), vol. 2, pp. 304-306, 2018.

[2] R. B. Ekelund Jr., "Jules dupuit and the early theory of marginal cost pricing," Journal of Political Economy, vol. 76, no. 3, pp. 462-471, 1968.

[3] L. Wilson, "A practical method for environmental impact assessment audits," Environmental Impact Assessment Review, vol. 18, no. 1, pp. 59-71, 1998.

[4] H. B. Deng, "Study on method of investment environment evaluation," Journal of Huazhong Normal University, vol. 33, no. 1, pp. 152-156, 1999.

[5] P. F. Zhu and Y. Tang, "Research on the integrated high-order moment portfolio strategy from time-frequency domain perspective," Systems Engineering-Theory \& Practice, vol. 40, no. 1, pp. 13-27, 2020.

[6] S. C. Narula, J. F. Wellington, and S. A Lewis," "Valuating residential real estate using parametric programming," $E u$ ropean Journal of Operational Research, vol. 217, no. 1, pp. 120-128, 2003.

[7] J. Q. Wang, J. P. Xi, and E. H. Xi, "Analysis on investment benefit of expressway reconstruction project," Journal of Highway and Transportation Research and Development, vol. 5, pp. 142-146, 2010.

[8] C. D. Chen and M. Y. Zhang, "Investment decision for highway project based on risk analysis," China Journal of Highway and Transport, vol. 1, pp. 99-103, 2006.

[9] X. Sun, "Research on multi objective decision-making of road investment project," Journal of Wuhan University of Technology: Transportation Science \& Engineering, vol. 30, no. 4, pp. 615-618, 2007.

[10] T. Zhan, X. Wang, and R. Liu, "Research on matter element model of investment decision for highway," Journal of Wuhan University of Technology: Transportation Science \& Engineering, vol. 33, no. 4, pp. 722-725, 2009.

[11] J. X. Chen, "Application of cost-benefit analysis method in highway infrastructure decision making," Transportation Science and Technology, vol. 26, no. 10, pp. 139-142, 2013.

[12] Z. B. Wang, "Guangxi expressway investment model based on regression analysis," Western China Communications Science \& Technology, vol. 4, pp. 13-15, 2016.

[13] L. Ma, M. J. Tan, X. D. Yang et al., "Design and development of expressway investment decision support system," Technology of Highway and Transport, vol. 6, pp. 119-123, 2019.

[14] G. Y. Zhao, P. Wu, X. F. Zhu et al., "Priority evaluation of green mining technology in sanshandao gold mine based on grey correlation analysis," Gold Science and Technology, vol. 6, pp. 835-843, 2019.

[15] C. Yuan, D. Wu, and H. Liu, "Using grey relational analysis to evaluate energy consumption, $\mathrm{CO}_{2}$ emissions and growth patterns in China's provincial transportation sectors,"
International Journal of Environmental Research and Public Health, vol. 14, no. 12, p. 1536, 2017.

[16] D. D. Wu, Y. Zhang, and D. Wu, "Fuzzy multi-objective programming for supplier selection and risk modeling: a possibility approach," European Journal of Operational Research, vol. 200, no. 3, pp. 774-787, 2009.

[17] C. C. Hsu and C. Y. Chen, "Regional load forecasting in Taiwan-applications of artificial neural networks," Energy Conversion \& Management,vol. 44, no. 12, pp. 1941-1949, 2005.

[18] H. Wong, B. Q. Hu, W. C. Ip et al., "Change-point analysis of hydrological time series using grey relational method," Journal of Hydrology, vol. 324, no. 1-4, pp. 323-338, 2006.

[19] J. J. Fu, S. M. Qiu, H. B. Zhao et al., "Study on impact factors of slope stability based on grey correlation analysis," Journal of Yangtze River Scientific Research Institute, vol. 1, pp. 53-57, 2011.

[20] J. L. Su and Y. F. Yang, "Highway value analysis based on grey system theory," China Journal of Highway and Transport, vol. 5, pp. 139-144, 2017.

[21] W. Q. Wang and Y. J. Wang, "Research on comparison and evaluation index system of highway construction plans," Traffic Engineering, vol. 19, no. A1, pp. 39-47, 2019.

[22] JTG D20-2006, Design Specification for Highway Alignment, Highway Administration, Beijing, China, 2011.

[23] JTG B01-2014, Technical Standard of Highway Engineering, Highway Administration, Beijing, China, 2014.

[24] JTG C30-2015, Hydrological Specifications for Survey and Design of Highway Engineering, Highway Administration, Beijing, China, 2015.

[25] JTG/T D31-05-2017, Technical Specifications for Design and Construction of Highway Subgrade in Loess Region, Highway Administration, Beijing, China, 2017.

[26] JTG G10-2016, Supervision Specification for Construction of Highway Engineering, Highway Administration, Beijing, China, 2016.

[27] JTG F90-2015, Safety Technical Specifications for Highway Engineering Construction, Highway Administration, Beijing, China, 2015.

[28] JTG B03-2006, Specifications Environmental Impact Assessment Highways, Highway Administration, Beijing, China, 2006.

[29] JTG C20-2011, Code for Highway Engineering Geological Investigation, Highway Administration, Beijing, China, 2011.

[30] Y. Wang, G. S. Zheng, P. Wang et al., "Identification method of critical nodes in road network with grey relational grade and entropy method," Journal of Military Transportation University, vol. 6, pp. 84-87, 2015.

[31] A. X. Li, Y. X. Liu, and J. J. Gao, "Comparison of risk assessment methods for low visibility on expressway," Advances in Meteorological Science and Technology, vol. 7, no. 6, pp. 11-17, 2017.

[32] J. Y. Hou, "Evaluation method for metro operation safety based on entropy weight method," Tunnel Construction, vol. 12, pp. 1465-1470, 2016.

[33] B. Llamazares, "Using interval weights in MADM problems," Computers \& Industrial Engineering, vol. 136, pp. 345-354, 2019.

[34] X. Jinliang, Z. Yuming, W. Yuping et al., "Evaluation index system of highway traffic value in Northwest China," Journal of Chang'an University: Natural Science, vol. 34, no. 22, pp. 79-87, 2014.

[35] G. Bu and Y. Zhang, "Grey fuzzy comprehensive evaluation based on the theory of grey fuzzy relation," Systems Engineering-Theory \& Practice, vol. 22, no. 4, pp. 141-144, 2002. 
[36] J. W. K. Chan and T. K. L. Tong, "Multi-criteria material selections and end-of-life product strategy: grey relational analysis approach," Materials \& Design, vol. 28, no. 5, pp. 1539-1546, 2007.

[37] D. Yang and N. Tian, "Sustainable development evaluation of expressway ecology of Gansu province," Journal of Northwest Normal University, vol. 5, no. 43, pp. 102-107, 2007.

[38] Q. S. Zhang, "Difference information entropy in grey theory," Journal of Grey System, vol. 13, no. 2, pp. 21-25, 2001.

[39] G. Ferrari and T. Laureti, "Evaluating technical efficiency of human capital formation in the Italian University: evidence from Florence," Statistical Methods and Applications, vol. 14, no. 2, pp. 243-270, 2005. 